\title{
Regulation of Structure-Specific Endonucleases in Replication Stress
}

\author{
Seong Min Kim and Susan L. Forsburg *(D) \\ Program in Molecular \& Computational Biology, University of Southern California, Los Angeles, CA 90089, \\ USA; seongmk1@gmail.com \\ * Correspondence: forsburg@usc.edu; Tel.: +1-213-740-7342
}

Received: 9 November 2018; Accepted: 12 December 2018; Published: 14 December 2018

\begin{abstract}
Replication stress results in various forms of aberrant replication intermediates that need to be resolved for faithful chromosome segregation. Structure-specific endonucleases (SSEs) recognize DNA secondary structures rather than primary sequences and play key roles during DNA repair and replication stress. Holliday junction resolvase MUS81 (methyl methane sulfonate (MMS), and UV-sensitive protein 81) and XPF (xeroderma pigmentosum group F-complementing protein) are a subset of SSEs that resolve aberrant replication structures. To ensure genome stability and prevent unnecessary DNA breakage, these SSEs are tightly regulated by the cell cycle and replication checkpoints. We discuss the regulatory network that control activities of MUS81 and XPF and briefly mention other SSEs involved in the resolution of replication intermediates.
\end{abstract}

Keywords: replication stress; structure-specific endonuclease; Mus81; XPF

\section{Introduction}

The DNA replication fork is sensitive to a variety of intrinsic and extrinsic stresses (reviewed in [1,2]). Endogenous blocks include collisions with transcription apparatus, natural pausing sites, and unusual DNA structures or sequences (reviewed in [3]). Highly repetitive DNA sequences (e.g., ribosomal DNA, telomeres) or common fragile sites (CFS) are also more prone to replication stress (reviewed in [4,5]). External agents that disrupt replication include depletion of deoxyribonucleotide triphosphate (dNTP) by hydroxyurea (HU) and DNA lesions caused by ultraviolet (UV) radiation, alkylating agents such as methyl methane sulfonate (MMS), or the topoisomerase inhibitor camptothecin (CPT) (reviewed in [1]).

Replication stress can result in accumulation of single stranded DNA, chromosome breaks, and rearrangements, which are deleterious to the cell (reviewed in [1,2]). Additionally, it may generate aberrant intermediates including DNA secondary structures, DNA lesions, and protein-DNA complexes (reviewed in [4]). Not surprisingly, increased replication stress is now recognized as a contributor to oncogenesis (e.g., reviewed in [6,7]).

A subset of structure-specific endonucleases (SSEs) that recognize specific DNA structures rather than DNA sequences, plays a crucial role in processing these aberrant structures to ensure replication fork stability and progression (reviewed in [8]). These SSEs are essential to maintaining genome stability, coordinating with the cell cycle to ensure that cells do not enter mitosis with structures that would promote improper chromosome segregation and breakage (reviewed in [9]). In this review we describe SSEs involved in processing DNA replication intermediates directly or indirectly regulated by the replication checkpoint (Figure 1). We pay particular attention to two conserved, related SSEs: Mus81 (MMS and UV-sensitive protein 81) and XPF (xeroderma pigmentosum group F-complementing protein). 


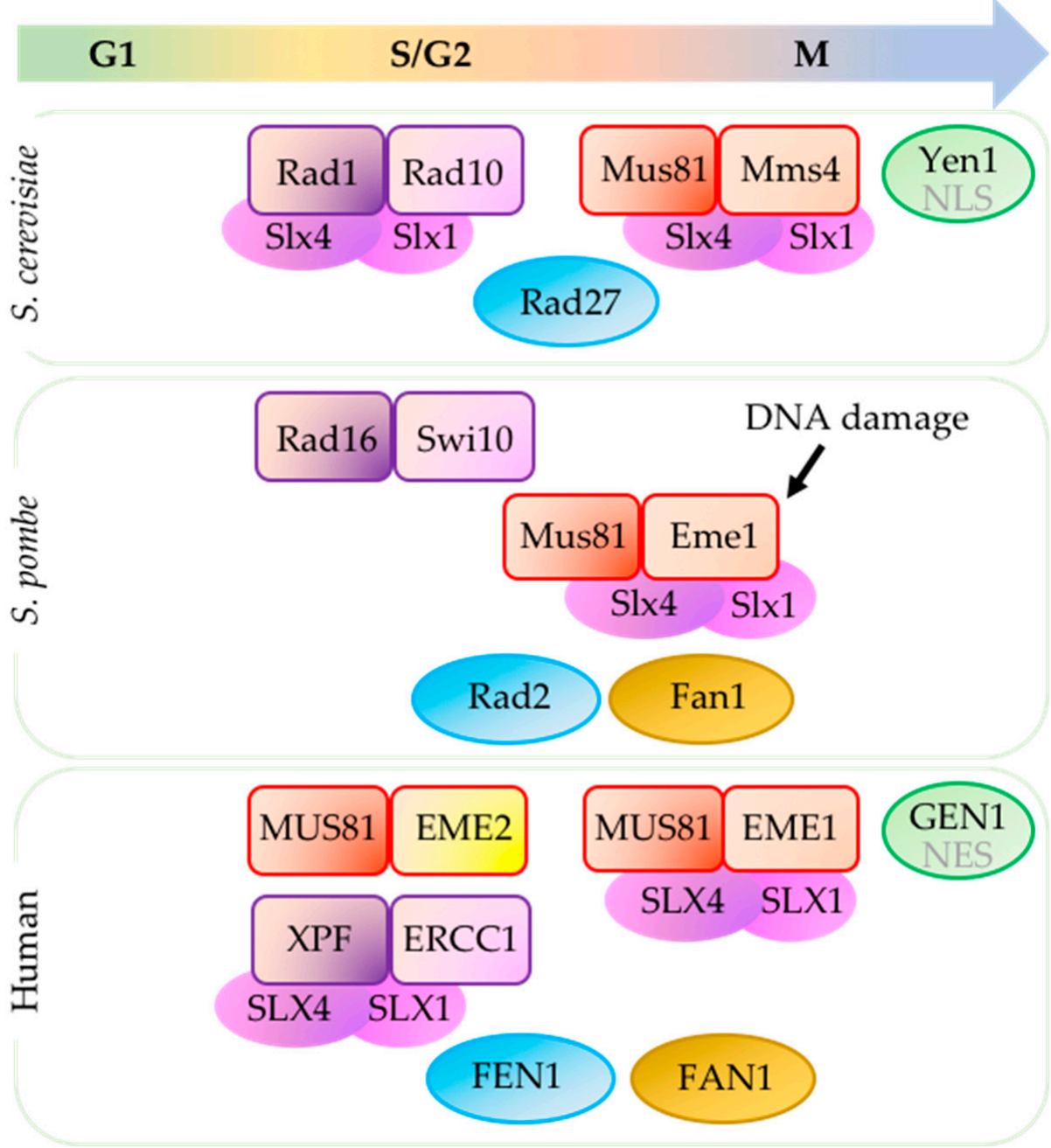

Figure 1. Structure-specific endonucleases (SSEs) in different phases of the cell cycle. Mus81 (methyl methane sulfonate (MMS) and UV-sensitive protein 81) activity in Saccharomyces cerevisiae and human cells is stimulated during G2-M transition (reviewed in [8]). In Schizosaccharomyces pombe, Mus81 is activated by DNA damage. Xeroderma pigmentosum group F complementing protein (XPF)-excision repair cross-complementing group 1 (ERCC1) (orthologs Rad1-Rad10 S.c. and Rad16-Swi10 S.p.) is important for various DNA repair pathways and cleaves replication intermediates during S and G2 phases [10]. Scaffold protein SLX4 with associating partner SLX1 interacts with MUS81-EME1 (essential meiotic endonuclease 1) and XPF-ERCC1 in human cells (reviewed in [11]) [12-15] and their orthologs in in S. cerevisiae (reviewed in [16]) [17-20]. In contrast, Slx4 does not affect Rad16-Swi10 in S. pombe [21]. Activity of Yen $1^{\text {S.c. }}$ is prevented until anaphase by restricting its nuclear entry due to phosphorylation of nuclear localization signal (NLS) [22-24]. Due to nuclear export signal (NES), GEN1 in human cells is able to access chromosomes only after nuclear membrane breakdown during mitosis [25]. S. pombe do not have Yen1 ortholog (reviewed in [26]). FEN1 (flap endonuclease 1) (orthologs Rad27 S.c. and $\operatorname{Rad} 2^{\text {S.P. }}$ ) and FAN1 (Fanconi-associated nuclease I) (missing in S. cerevisiae) contribute to processing replication intermediates but cell cycle-dependent regulation of these SSEs are not well characterized (reviewed in [8]). Mms4 (methyl methane sulfonate sensitivity protein 4).

\section{Mus81-Essential Meiotic Endonuclease 1 (Schizosaccharomyces pombe)/Mus81-Mms4 (Saccharomyces cerevisiae)/MUS81-EME1/2 (Human)}

\subsection{Mus81 Processes Replication and Recombination Intermediates}

The Mus81 protein was identified for its role in processing complex branched DNA structures, including Holliday junctions, that form after complementary strand exchange between homologous 
sequences (reviewed in [27-32]). Mus81 can resolve synthetic Holliday junction structures in vitro [31,32] and has a high affinity for branched duplex DNA and replication fork substrates [33]. Consistent with this, loss of mus 81 leads to severed meiotic defects, resulting in abnormal chromosomal segregation defects in yeasts $[31,34,35]$. In fission yeast (Schizosaccharomyces pombe), it is essential to complete sister chromatid exchange at the mating locus $[31,36]$.

Mus81-dependent resolution of entangled sister chromatids is essential for survival of cells that depend on homology-directed repair of collapsed replication forks [36,37]. In human cells, MUS81 is similarly needed for replication fork restart after replication stress inducing agents [38-41]. MUS81deficient cells have decreased viability upon low-dose exposure to these replication inhibitors [41]. Importantly, fork restart in BRCA2 (breast cancer-associated protein 2)-deficient cells requires MUS81dependent cleavage of partially resected, regressed forks [42]. In addition to resolving replication intermediates, compensatory DNA synthesis during mitosis and cleavage of mitotic interlinks to allow chromosomal segregation also require MUS81 [43]. These and many more studies demonstrate Mus81 plays a critical role to resolve replication and recombination intermediates and ensure proper chromosome segregation during cell division.

But Mus81 is a double-edged sword. Unregulated activity can have deleterious effects. Mus81 causes replication stress-induced double stranded breaks (DSB) in mammalian cells [38] and promotes deletion mutations in pol $\alpha$ mutant fission yeast [44]. When an active replication fork converges on a collapsed fork, replication termination is prone to Mus81-dependent deletions between repetitive DNA sequences in fission yeast [45]. In human cells, oncogene-induced chromosomal breakage involves MUS81 activity [46]. These findings suggest that tight regulation of Mus81 is necessary to repair replication-associated DNA structures without inducing unnecessary DNA cleavage.

\subsection{Regulation of Mus81 by Cell Cycle Kinases}

A key component of that regulation is cell cycle- and checkpoint-dependent regulation of Mus81. These restrict its activity to later in the cell cycle in unstressed cells. The Mus 81 enzyme forms a complex with Eme1 (essential meiotic endonuclease 1) which creates a stable interaction with a DNA substrate for the complex [47]. Phosphorylation of Eme1 by various cell cycle kinases provide one mechanism to regulate Mus81 activity. In budding yeast (Saccharomyces cerevisiae), Mus81 forms a complex with the Eme1 ortholog Mms4 (methyl methane sulfonate sensitivity protein 4) [8]. Mus81-Mms4 $4^{\text {S.c. }}$ is activated in a cell cycle-dependent manner and depends on phosphorylation of $\mathrm{Mms}^{\text {S.c. }}$ by the cell cycle kinases Cdc28 ${ }^{\text {S.c. }}$ (CDK1 in human) and Cdc5 ${ }^{\text {S.c. }}$ (PLK1 in human) at the G2/M transition (Figure 2) [48-50]. This restricts Mus81-Mms4 ${ }^{\text {S.c. }}$ activity during S-phase to prevent unnecessary cleavage of DNA substrates while DNA replication is occurring [48,51]. Via the scaffold protein Rtt107 ${ }^{\text {S.c. }}$, Cdc7-Dbf4 $4^{\text {S.c. }}$ (Dbf4-dependent kinase, DDK) interacts with and phosphorylates Mus81-Mms4, which is required for Mus81 activation during mitosis [52].

In fission yeast, which spends of most of its lifetime in G2 phase, Mus81-Eme1 $1^{\text {S.p. }}$ activity is upregulated in response to DNA damage [8]. Cdc2 $2^{\text {S.p. }}$ (CDK1 in human) phosphorylation of Eme1 $1^{\text {S.p. }}$. primes it for phosphorylation and activation by the DNA damage sensor and checkpoint activator

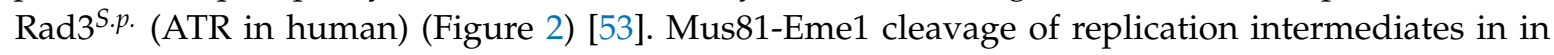
turn may have a role in activation or propagation of checkpoint pathways. Deletion of Mus $81^{\text {S.p. }}$ in replication stress-induced, temperature-sensitive Mcm4 helicase mutant ( $m c m 4-t s$ ) results in failure to maintain the DNA damage checkpoint and in subsequent abnormal chromosomal segregation [54].

In human cells, MUS81 is up-regulated at the onset of mitosis and has two partners, EME1 and EME2 [8,55]. Approximately $80 \%$ of MUS81 is associated with EME1 while the remaining $20 \%$ is associated with EME2 (reviewed in [56]). It is not obvious whether EME1 or EME2 is responsible for S phase-specific functions of MUS81 [55,57]. Interestingly, MUS81-EME1 activity is needed for maintaining replication fork speed [57] while MUS81-EME2 activity promotes replication fork restart and chromosomal stability [55]. 
S. cerevisiae

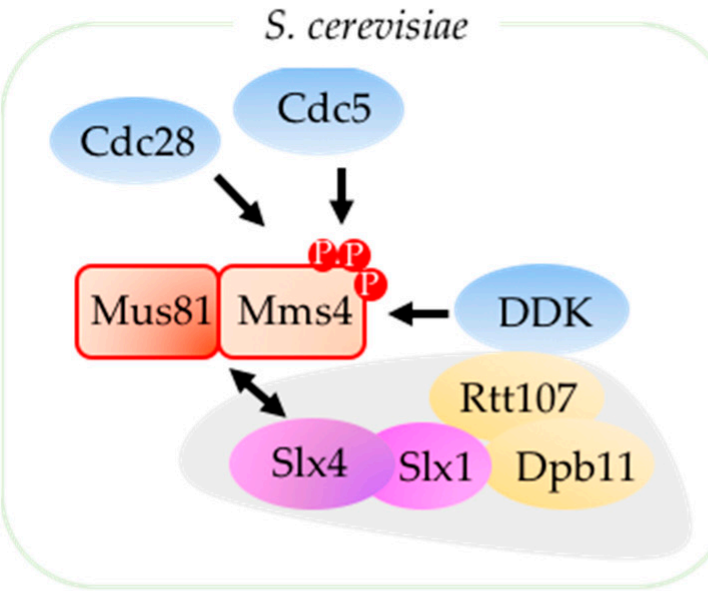

\section{S. pombe}

\section{DNA damage}

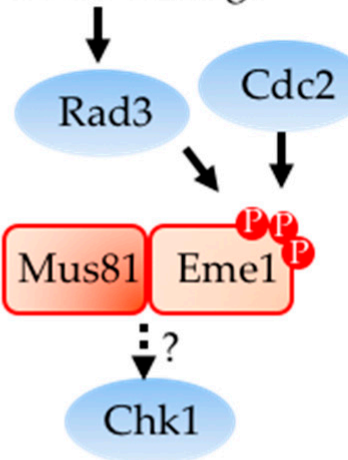

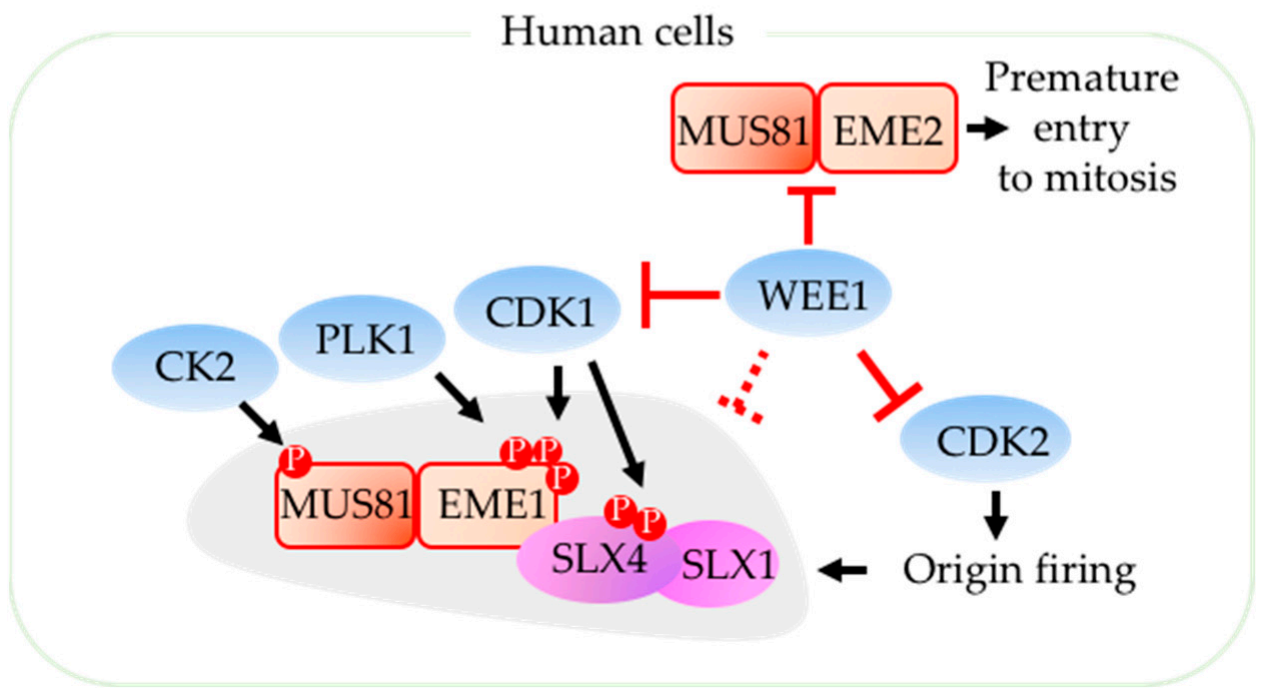

Figure 2. Mus81 regulation by cell cycle kinases. In S. cerevisiae, Mus81-Mms4 is phosphorylated by $\mathrm{Cdc} 28^{\text {S.c. }}$ (CDK1 ortholog) and $\mathrm{Cdc}^{\text {S.c. }}$ (PLK ortholog) kinases at the G2/M transition [48-50]. Scaffold protein Rtt107 S.c. (PTIP ortholog) associates with Dpb11 ${ }^{\text {S.c. }}$ (TOPBP1 ortholog) and interacts

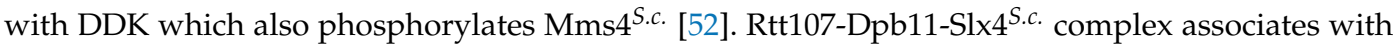
Mus81-Mms4 ${ }^{\text {S.c. }}$ behind replication forks. In S. pombe, Mus81-Eme1 $1^{\text {S.p. }}$ is phosphorylated by Cdc2 ${ }^{\text {S.p. }}$. (CDK1 ortholog) which primes Eme1 ${ }^{\text {S.p. }}$ for phosphorylation by Rad3 ${ }^{\text {S.p. }}$ (ATR ortholog) upon DNA damage [53]. Mus81-Eme1 $1^{\text {S.p. }}$ may be contributing to Chk1 activation in fission yeast as Mus81-deleted cells with replication defect are able to bypass Chk1 checkpoint [54]. In human cells, MUS81-EME1 activity peak during M phase after EME1 is phosphorylated by CDK1, PLK1 [12,58,59]. SLX4 phosphorylation by CDK1 and MUS81 phosphorylation by CK2 also promotes MUS81-EME1 activity [60]. During S-phase, WEE1 downregulates MUS81-EME1 activity by inhibiting CDK1 and thereby limiting EME1 and SLX4 phosphorylation (reviewed in [56]). WEE1 inhibition of CDK2 reduces origin firing and subsequently the replication intermediate substrates of MUS81. WEE1 may also inhibit MUS81 directly [61]. Residual MUS81 activity during S-phase comes from MUS81 that forms complex with EME2 which can promote premature entry to mitosis upon WEE1 inhibition [62].

MUS81-EME1 activity in human cells peaks during M phase after hyperphosphorylation of EME1 by cell cycle kinases CDK1 and PLK1 (Figure 2) [12,58,59]. Uninhibited CDK1 activity results in chromosomal fragmentation following premature activation of MUS81 [63], further linking CDK to MUS81 activity. PLK1 promotes DNA repair protein BRCA1 recruitment to facilitate MUS81-mediated fork cleavage coupled with a break-induced replication [64]. Moreover, PLK1 interaction with BRCA1 and CDK1 activation of RECQ5 DNA helicase promotes MUS81-EME1 recruitment to CFS [65]. A recent study showed that the pleiotropic serine/threonine kinase CK2 kinase is able to phosphorylate MUS81 
in late-G2/mitosis and upon mild replication stress to promote its association with EME1 and scaffold protein SLX4, another stimulator of MUS81 activity [60]. These findings show that cell cycle-dependent kinases not only play a crucial role in restricting Mus81 activity to appropriate timing of the cell cycle but also contribute to Mus81-dependent DNA repair.

Other regulators down-regulate S-phase activity of MUS81. WEE1, a well-known inhibitor of CDKs, suppresses MUS81 activity during S-phase by: (1) Potentially phosphorylating MUS81, (2) by inhibiting CDK2 and thereby limiting origin firing and replication stress, and (3) by restraining CDK1 that phosphorylates and activates EME1 and scaffold protein SLX4 (Figure 2) (reviewed in [56]). In the absence of WEE1, MUS81-EME1 activity results in unnecessary replication fork cleavage, leading to accumulation of DNA damage [61,66]. Deletion of MUS81 in the absence of WEE1 reduces DSB [61] but does not prevent activation of ATR and CHK1 [67], suggesting that MUS81 activity is downstream of replication fork stalling and S-phase checkpoint. This is also evidenced by the detrimental MUS81dependent processing of replication intermediates following CHK1 inhibition [68-70]. Although the mechanistic details are unknown, these findings indicate that CHK1 down-regulates MUS81 in human cells (Figure 3).

Unlike CDK1-and PLK1-regulated control of MUS81-EME1 activity, the control of MUS81-EME2 activity is not well-established despite the evidence that MUS81-EME2 is responsible for the DNA damage during premature entry to mitosis upon WEE1 inhibition [62]. Because deletion of MUS81 or EME2 delays premature entry into mitosis induced by WEE1 inhibition, this suggests that regulating MUS81-EME2 activity may be the mechanism by which WEE1 prevents premature mitotic entry (Figure 2) [8,62].

\subsection{Mus81 is Regulated by the Replication Checkpoint during Replication Stress}

During replication stress, Mus81 plays a crucial role in processing abnormal replication intermediates. It is recruited to sites of replication blockage to resolve replication intermediates and inhibits anaphase bridge formation, preventing chromosome mis-segregation and transmission of damaged DNA to daughter cells (reviewed in [71-73]). Loss of Mus81 attenuates recovery of stalled replication forks and makes cells hypersensitive to DNA damaging agents that obstruct replication fork progression [29,38,39,74-77]. Paradoxically, although Mus81 is required to resolve aberrant replication intermediates, it can also create DNA breaks that threaten genomic stability. This is why Mus 81 regulation during replication stress is crucial. Upon replication disturbance, the replication checkpoint pathway is activated to resolve replication hindrances and to delay mitosis until the replication stress is relieved (reviewed in [27,78]).

$\mathrm{Cds}^{\text {S.p. }}$ is the fission yeast replication checkpoint effector (Figure 3). In budding yeast, the Cds $1^{\text {S.p. }}$ homolog Rad53 ${ }^{\text {S.c. }}$ is the effector of both the DNA damage checkpoint and the replication checkpoint. Fission yeast $\mathrm{Cds} 1^{\text {S.p. }}$ acts downstream of DNA-dependent protein kinase-like family $\operatorname{Rad}^{\text {S.p. }}$ (Mec1 $1^{\text {S.c. }} /$ ATR in human) (reviewed in [79]). Upon replication stress, a conserved mediator protein $\mathrm{Mrc1}^{\text {S.p. }}$ (CLASPIN in human) is phosphorylated by Rad3 $3^{\text {S.p. }}$ which then recruits $\mathrm{Cds} 1^{\text {S.p. }}$ to stalled replication forks to be activated (reviewed in [80,81]). 


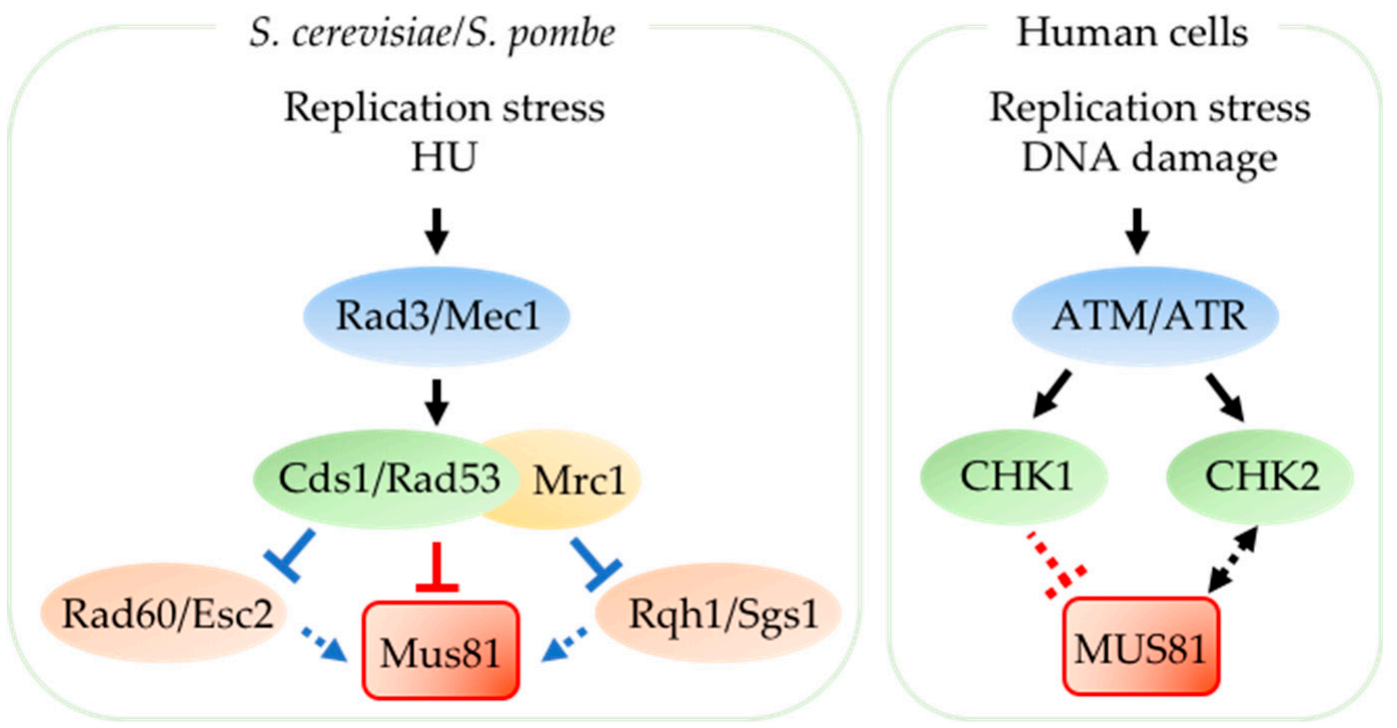

Figure 3. Mus81 regulation by replication checkpoint. In yeast, replication stress induces $\operatorname{Rad} 3^{\text {S.p. }} / \mathrm{Mec} 1^{\text {S.c. }}$. (ATR in human) activation of $\mathrm{Cds} 1^{\text {S.p. }} / \mathrm{Rad} 53^{\text {S.c. }}$ by promoting its association with $\mathrm{Mrc1} 1^{\text {S.p./S.c. }}$ (CLASPIN in human) (reviewed in [80]). Upon acute and severe replication stress such as hydroxyurea treatment, $\mathrm{Cds} 1^{\text {S.p. }}$ limits Mus $81^{\text {S.p. }}$ activity (indicated by solid red line) [44]. Cds1 ${ }^{\text {S.p. }}$ inhibits Rad60 S.p. activity (indicated by blue line) by promoting delocalization from the nucleus $[82,83]$. Mrc1 ${ }^{\text {S.p./S.c. }}$ protein level regulates recruitment of $\mathrm{Rqh}^{\text {S.p. }}$ homolog Sgs1 ${ }^{\text {S.c. }}$ to chromatin (indicated by blue arrow) [74]. Both Rad60 S.p. $/ \mathrm{Esc}^{\text {S.c. }}$ and Rqh1 ${ }^{\text {S.p. }} / \mathrm{Sgs} 1^{\text {S.c. }}$ contribute to Mus 81 activity (indicated by dashed blue arrow) $[75,76]$. In human cells, DNA damage checkpoint CHK1 and Cds1-homolog CHK2 is activated downstream of ATM/ATR kinases (reviewed in [79,80]) [77]. It is unclear whether MUS81 is directly regulated by these checkpoint kinases in human cells. However, there is evidence that CHK2 upregulates MUS81 protein levels and MUS81 in turn contributes to CHK2 activation upon DNA damage (indicated by dashed double-headed arrow) [84]. Deleterious MUS81-dependent processing of replication intermediates following CHK1 inhibition suggests that CHK1 downregulates MUS81 activity (indicated by dashed red line) [68-70].

In fission yeast, $\mathrm{Cds} 1^{\text {S.p. }}$ is necessary to prevent accumulation of aberrant replication intermediates, indicating that $\mathrm{Cds} 1^{\text {S.p. }}$. regulates resolution of damaging DNA structures at replication forks (reviewed in [85]) [86-91]. Mus81 S.p. is a key target downstream of Cds1 ${ }^{\text {S.p. }}[29,31,32,44]$. This S-phase checkpoint kinase tightly regulates Mus $81^{\text {S.p. }}$ to prevent uncontrolled nuclease activity during DNA replication. Mus $81^{\text {S.p. }}$ associates with $2-5 \%$ of the Cds $1^{\text {S.p. }}$. protein through a forkhead-associated (FHA) domain on $\mathrm{Cds}^{\text {S.p. }}$ and is phosphorylated in $\mathrm{Cds}^{\text {S.p. }}$-dependent manner upon replication stress $[29,92]$. Acute $\mathrm{HU}$ treatment results in phosphorylated Mus $81^{\text {S.p. }}$. dissociating from the chromatin to prevent extensive cleavage of replication intermediates [44]. Loss of Cds1-Mus81 S.p. interaction via mutations in the FHA domain of Cds1 $1^{\text {S.p. }}$ or FHA-binding site on Mus81 ${ }^{\text {S.p. }}$ abolishes HU-induced Mus81 ${ }^{\text {S.p. }}$. phosphorylation, so that Mus $81^{\text {S.p. }}$. remains associated with chromatin with deleterious effects [44]. On the other hand, chronic low dose HU-treatment reduces Cds1 $1^{\text {S.p. }}$-mediated inhibition of Mus81 $1^{\text {S.p. }}$ activity and this allows processing of DNA secondary structures that form during extended replication block [44].

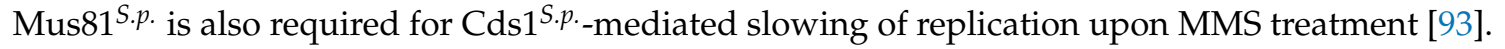

In addition to phosphorylating Mus $81^{\text {S.p. }}$, Cds $1^{\text {S.p. }}$ may also indirectly modulate Mus $81^{\text {S.p. }}$. activity by regulating proteins that function closely with Mus $81^{\text {S.p. }}$ to respond to damage during replication (Figure 3). For instance, the DNA repair protein Rad60 ${ }^{S . p}$. and RecQ family DNA helicase Rqh1 $1^{\text {S.p. }}$ function coordinately with Mus $81^{\text {S.p }}$ in recombinational repair (reviewed in [78]). $\mathrm{Cds}^{\text {S.p. }}$ down-regulates nuclear localization of Rad60 ${ }^{\text {S.p. }}$ in replication-arrested cells $[82,83]$ and small ubiquitin-related modifier (SUMO)-like domains of Rad60 $0^{\text {S.p }}$ homolog Esc2 ${ }^{\text {S.c. }}$ in budding yeast are critical for stimulation of Mus81 ${ }^{\text {S.c. }}$ [75]. Moreover, $\mathrm{Rqh}^{\text {S.p. }}$. contributes to the formation of 
Mus81 $1^{\text {S.p. }}$-mediated DSB in Cds1 $1^{\text {S.p. }}$-deleted cells [76]. In budding yeast, $\mathrm{Cds} 1^{\text {S.p. }} / \mathrm{Rad} 53^{\text {S.c. }}$ activator $\mathrm{Mrc}^{\text {S.p./S.c. }}$ protein level regulates recruitment of $\mathrm{Rqh1}^{\text {S.p. }}$ homolog Sgs1 ${ }^{\text {S.c. }}$ to chromatin [74]. $\mathrm{Cds} 1^{\text {S.p. }} / \mathrm{Rad}_{53}{ }^{\text {S.c. }}$ regulation of $\operatorname{Rad} 60^{\text {S.p. }} / \mathrm{Esc}^{\text {S.c. }}$, $\mathrm{Rqh} 1^{\text {S.p. }} / \mathrm{Sgs} 1^{\text {S.c., }}$, and possibly other proteins involved in resolving replication fork stress may be an important coordinator of Mus $81^{S . p}$ activity.

In mammalian cells, DNA damage checkpoint kinase $\mathrm{CHK} 1$ and $\mathrm{Cds} 1^{\text {S.p. }}$-homolog CHK2 are activated downstream of ATM/ATR kinases in response to certain replication blocks and to DNA damage during S-phase (reviewed in [79]) [77]. Although Cds1-Mus81 S.p. interaction is conserved in human cells (CHK2-MUS81), it is unclear if CHK2 directly regulates MUS81 as in fission yeast (reviewed in [8]), although there is evidence that CHK2 up-regulates the protein level of MUS81; MUS81 in turn contributes to activation of CHK2 in Cisplatin-treated breast cancer cells (Figure 3) [84].

\subsection{Other Regulators of Mus81 Recruitment and Activity}

There is growing evidence that there are other regulators of Mus 81 activity besides cell cycle and replication checkpoint kinases (Table 1). For example, the N-terminal fragment of DNA repair protein Rad52 ${ }^{\text {S.c. }}$ stimulates the endonuclease activity of Mus81-Mms4 $4^{\text {S.c. }}$ on homologous recombination intermediates in budding yeast [94]. RAD52 also promotes MUS81-mediated break-induced replication repair of collapsed forks and mitotic DNA synthesis in human cells $[95,96]$. The small ubiquitin-related modifier (SUMO)-like domain of the adaptor protein establishment of silent chromatin 2 (Esc2 ${ }^{\text {S.c. }}$ ) in budding yeast interacts with and stimulates Mus81-Mms4 $4^{\text {S.c. }}$ catalytic activity [75]. The replication factor C (RFC) complex and the loading of proliferating cell nuclear antigen (PCNA) also enhances recruitment and activity of Mus81-Mms4 $4^{\text {S.c. }}$ [97]. 


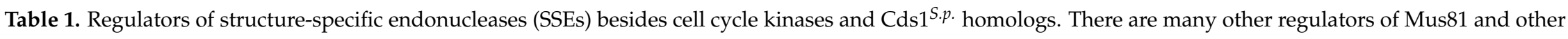
SSE activities besides cell cycle-dependent kinases. Proteins involved in DNA repair or replication are the most common regulators. (S.c.: S. cerevisiae; S.p.: S. pombe).

\begin{tabular}{|c|c|c|c|c|}
\hline $\begin{array}{l}\text { Grouping of Regulatory } \\
\text { Protein or Stimulus }\end{array}$ & $\begin{array}{l}\text { Protein or Stimulus that } \\
\text { Regulates SSE Activities }\end{array}$ & Organism & Effect on SSE & Reference \\
\hline \multicolumn{5}{|c|}{ Mus81-Eme1 (S. p.)/Mus81-Mms4 (S. c.)/MUS81-EME1 (human) } \\
\hline $\begin{array}{l}\text { Players of DNA } \\
\text { repair or replication }\end{array}$ & $\begin{array}{c}\text { Rad52 } \\
\text { Esc2 } \\
\text { RFC/PCNA } \\
\text { FANCD2 } \\
\text { RECQ5 helicase }\end{array}$ & $\begin{array}{l}\text { S. c., Human } \\
\text { S.c. } \\
\text { S.c. } \\
\text { Human } \\
\text { Human }\end{array}$ & $\begin{array}{c}\text { Stimulate activity } \\
\text { Stimulate activity } \\
\text { Stimulate activity } \\
\text { Promote recruitment \& activity } \\
\text { Promote recruitment to CFS }\end{array}$ & $\begin{array}{c}94-96] \\
{[75]} \\
{[97]} \\
\text { Rev. in }[98,99] \\
{[65]}\end{array}$ \\
\hline SMC protein complex & $\begin{array}{l}\text { Smc5/6 } \\
\text { SMC2 } \\
\text { WAPL } \\
\text { Psm1 }\end{array}$ & $\begin{array}{l}\text { S. c., Human } \\
\text { Human } \\
\text { Human } \\
\text { S.p. }\end{array}$ & $\begin{array}{c}\text { Stimulate activity } \\
\text { Promote recruitment } \\
\text { Promote recruitment } \\
\text { Stimulate activity }\end{array}$ & $\begin{array}{c}{[99,100]} \\
{[101]} \\
{[101]} \\
{[102]}\end{array}$ \\
\hline Localization & $\begin{array}{c}\text { Nucleolar } \\
\text { DNA damage-induced }\end{array}$ & $\begin{array}{l}\text { Human } \\
\text { S. c., Human }\end{array}$ & $\begin{array}{l}\text { Maintains repetitive nucleolar DNA } \\
\text { Maintains genome stability after DNA damage }\end{array}$ & $\begin{array}{c}{[103]} \\
{[103,104]}\end{array}$ \\
\hline Post-translational modifier & SUMOylation & Human & Stimulate activity upon arsenic treatment & [105] \\
\hline Epigenetic modifier & EZH2 & Human & Methylation on H3K27 at stalled replication fork stimulate recruitment & [106] \\
\hline Scaffold protein & $\begin{array}{l}\text { SLX4 } \\
\text { UHRF1 }\end{array}$ & $\begin{array}{l}\text { S. c., Human } \\
\text { Human }\end{array}$ & $\begin{array}{l}\text { Promote recruitment \& activity } \\
\text { Promote recruitment }\end{array}$ & $\begin{array}{l}{[11-15,60]} \\
{[107,108]}\end{array}$ \\
\hline \multicolumn{5}{|c|}{ Rad16-Swi10 (S. p.)/Rad1-Rad10 (S. c.)/XPF-ERCC1 (human) } \\
\hline $\begin{array}{l}\text { Players of DNA } \\
\text { repair or replication }\end{array}$ & $\begin{array}{c}\text { Rad14 } \\
\text { RPA } \\
\text { Rad52 } \\
\text { FANCD2 }\end{array}$ & $\begin{array}{l}\text { S.c. } \\
\text { Human } \\
\text { Human } \\
\text { Human }\end{array}$ & $\begin{array}{l}\text { Promote recruitment } \\
\text { Stimulate activity } \\
\text { Stimulate activity } \\
\text { Promote recruitment }\end{array}$ & $\begin{array}{c}{[109]} \\
{[110,111]} \\
{[110,112]} \\
\text { Rev. in }[98,99]\end{array}$ \\
\hline Scaffold protein & $\begin{array}{l}\text { Pxd1 } \\
\text { SLX4 } \\
\text { UHRF1 }\end{array}$ & $\begin{array}{l}\text { S.p. } \\
\text { S. c., Human } \\
\text { Human }\end{array}$ & $\begin{array}{c}\text { Stimulate activity } \\
\text { Promote recruitment \& activity } \\
\text { Promote recruitment }\end{array}$ & $\begin{array}{c}{[113]} \\
{[11-15]} \\
{[107,108]}\end{array}$ \\
\hline DNA binding protein & Saw1 & S.c. & Promote recruitment & [114] \\
\hline \multicolumn{5}{|c|}{$\operatorname{Rad2(S.p.)/\operatorname {Rad}27(S.c.)/\text {FEN1(human)}}$} \\
\hline $\begin{array}{l}\text { Players of DNA } \\
\text { repair or replication }\end{array}$ & $\begin{array}{c}\text { PCNA } \\
\text { Rad9-Rad1-Hus1 complex } \\
\text { MUS81 } \\
\text { RECQ5 helicase WRN }\end{array}$ & $\begin{array}{l}\text { Human } \\
\text { Human } \\
\text { Human } \\
\text { Human }\end{array}$ & $\begin{array}{l}\text { Promote recruitment \& activity during Okazaki fragment maturation } \\
\text { Promotes activity during replication stress } \\
\text { Stimulate activity } \\
\text { Promote recruitment \& activity }\end{array}$ & $\begin{array}{c}\text { Rev. in [115] } \\
{[116]} \\
{[117-119]} \\
{[120-122]}\end{array}$ \\
\hline Post-translational modifier & SUMOylation & Human & Promotes association with Rad9-Rad1-Hus1 complex & [116] \\
\hline \multicolumn{5}{|c|}{ Fan1(S. p.)/Absent in S. c./FAN1 (human) } \\
\hline $\begin{array}{l}\text { Players of DNA } \\
\text { repair or replication }\end{array}$ & $\begin{array}{c}\text { FANCD2 } \\
\text { PCNA }\end{array}$ & $\begin{array}{l}\text { Human } \\
\text { Human }\end{array}$ & $\begin{array}{l}\text { Promote recruitment } \\
\text { Promote recruitment }\end{array}$ & $\begin{array}{l}{[123]} \\
{[124]}\end{array}$ \\
\hline \multicolumn{5}{|c|}{ Absent in S. p./Yen1 S. c./GEN1 (human) } \\
\hline Localization & $\begin{array}{c}\text { Cdc28 } \\
\text { Cdc14 } \\
\text { Nuclear Export Signal }\end{array}$ & $\begin{array}{l}\text { S.c. } \\
\text { S.c. } \\
\text { Human }\end{array}$ & $\begin{array}{c}\text { Nuclear exclusion at G1/S } \\
\text { Nuclear import at anaphase } \\
\text { Nuclear exclusion until nuclear envelope breakdown }\end{array}$ & $\begin{array}{c}{[22-24]} \\
{[23]} \\
{[25]}\end{array}$ \\
\hline
\end{tabular}


Interestingly, the Structural Maintenance of Chromosomes (SMC) complexes are another modulator of Mus81 $81^{\text {S.p/S.c. }}$ activity. In yeast, for example, the Smc5-Smc6 ${ }^{\text {S.p/S.c. }}$ complex promotes Mus81 S.p/S.c. -dependent resolution of Holliday junctions [99,100]. The positive genetic interactions between certain mutants affecting methylation of cohesin subunit Psm1 $1^{\text {S.p. }}$ and Mus81-Eme $1^{\text {S.p. }}$ mutants in fission yeast suggests that methylation of cohesin subunits may be important for Mus81 activity at the stalled replication fork. Alternatively, Mus 81 may be required for recruitment of the cohesin to sites of DNA damage [102]. In human cells, depletion of SMC2, which is required for chromosome condensation, or WAPL (Wings apart protein-like), which is required for release of sister-chromatid arm cohesin, results in failure to recruit MUS81 to chromatin [101].

In human cells, post-translational modification of MUS81 other than phosphorylation may be important for its activity during DNA repair. This is evidenced by compromised DNA damage response in cells with SUMOlyation-resistant MUS81 upon arsenic treatment that mimic metal carcinogenesis [105]. Epigenetic modifications adjacent to replication forks may also contribute to regulation of MUS81 recruitment and activity. For instance, EZH2 (enhancer of zeste homologue 2) that methylates histone $\mathrm{H} 3$ on Lys27 (H3K27) at stalled replication forks has been shown to mediate recruitment of MUS81 [106].

Localization of MUS81 is another way its activity is modulated. In human cells, MUS81 accumulates in the nucleolus during $S$ phase, suggesting that it is required to maintain highly repetitive nucleolar DNA (reviewed in [8]). MUS81 relocates from the nucleolus to localized regions of UV damage specifically in S-phase cells [103]. Sub-localization of Mus81 ${ }^{\text {S.c. }}$ also occurs in budding yeast. Following DNA damage, Mus81-Mms4 $4^{\text {S.c. }}$ relocalizes to subnuclear foci and colocalizes with other endonucleases and with $\mathrm{Cmr}^{\text {S.c. }}$, a protein involved in genome stability maintenance [104]. Subnuclear

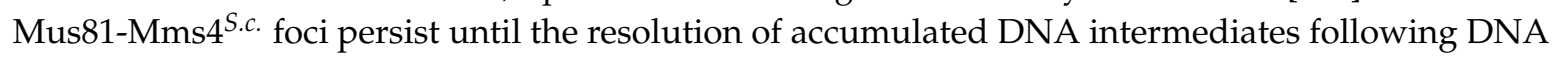
damage [104].

These findings demonstrate that cells are equipped with multiple means to tightly regulate Mus 81 recruitment and activity. Investigating how these various modulators of Mus81 communicate with each other will further elucidate Mus81-dependent genome stability maintenance.

\section{Rad16-Swi10 (Schizosaccharomyces pombe)/Rad1-Rad10 (Saccharomycescerevisiae)/Xeroderma Pigmentosum Group F Complementing Protein (XPF)-Excision Repair Cross-Complementing Group 1 (ERCC1) (Human)}

An additional SSE plays a related role to Mus81. Xeroderma pigmentosum group F complementing protein $(\mathrm{XPF})$-excision repair cross-complementing group 1 (ERCC1) heterodimer complex is a $5\left\ulcorner\right.$ ä-3 $3^{\sim}$ ä structure-specific endonuclease involved in a variety of DNA repair pathways including nucleotide excision repair (NER) and has important roles in interstrand crosslink (ICL) repair and DSB repair (reviewed in [125]). Rad16-Swi10 S.p. is the fission yeast ortholog and Rad1-Rad10 ${ }^{\text {S.c. }}$ is the budding yeast ortholog (reviewed in [8]).

With MUS81-EME1, XPF-ERCC1 processes under-replicated DNA and replication intermediates at CFS and prevents anaphase bridges following recruitment by SLX4 [72,73]. However, MUS81 and XPF may differ in the timing of their activity (Figure 1). In human cells, the biological function of MUS8-EME1 is mostly during mitosis although MUS81 activity is present throughout the cell cycle, probably through its association with EME2 (reviewed in [56]). During S- and G2-phase, XPF-ERCC1 along with another endonuclease ARTEMIS, are responsible for replication stress-induced fork cleavage needed to resume DNA replication [10]. Data from fission yeast indicates that Mus $81^{\text {S.p. }}$. and Rad16 $6^{\text {S.p. }}$ /XPF may direct repair towards different templates, with Mus81 $1^{\text {S.p. }}$ using the sister chromatid and Rad16 S.P. $/$ XPF using ectopic sequences [36].

Despite minimal overlap in substrate specificity in vitro [126], evidence suggests that XPF and MUS81 provide overlapping activity. Mammalian XPF is not required for viability $[127,128]$, possibly due to overlap with MUS81 or other SSEs [129-131]. XPF becomes essential in chicken DT40 cells if MUS81 is missing [132]. In fission yeast, a double mutant lacking both $\operatorname{Rad} 16^{\text {S.p. }} / \mathrm{XPF}$ and Mus $81^{\text {S.p. }}$ is 
inviable [21]. Consistent with this, XPF-ERCC1 partially compensates for MUS81 loss during mild replication stress in mammalian cells [41]. MUS81-EME1 also rescues the viability of XPF-deleted cells [132].

Association with different recruiting partners and stimulating proteins appears to determine in which repair pathway XPF-ERCC1 will function (Table 1). In fission yeast, a recently identified protein Pxd1 ${ }^{\text {S.p. }}$ (pombe XPF and Dna2) stimulates 3 ä-endonuclease activity of Rad16-Swi10 $0^{\text {S.p. }}$ [113]. In budding yeast, Saw $1^{\text {S.c. }}$ (Single-strand annealing weakened protein 1), a structure-specific DNA binding protein, recruits Rad1-Rad10 $0^{\text {S.c. }}$ to single-strand annealing repair sites [114] while damage recognition protein Rad14 ${ }^{\text {S.c. }}$ brings Rad1-Rad10 S.c. to NER [109]. In human cells, ERCC1 cannot enter the nucleus without XPF, demonstrating that XPF-ERCC1 heterodimer formation is critical [133]. In NER, XPF-ERCC1 cleavage of the damaged stand is stimulated by RPA and Rad52 [110,112]. RPA is also required for XPF-ERCC1 endonuclease activity in replication-coupled ICL repair [111]. In human cells, both XPF-ERCC1 and MUS81-EME1 are recruited to the replication fork stalled at ICL by the scaffold protein SLX4 and this depends on ubiquitylation of the FANCD2 (Fanconi anaemia complementation group D2) (reviewed in [98]) [134,135]. Independently of SLX4, the scaffold protein UHRF1 (ubiquitin-like PHD and RING finger domain-containing protein1) is needed to recruit FANCD2 and MUS81-EME1 and XPF-ERCC1 to DNA damage sites [107,108].

\section{Structure-Specific Endonuclease Subunit Slx4 (Schizosaccharomyces pombe)/Slx4 (Saccharomyces cerevisiae)/SLX4 (Human)}

In human cells and in budding yeast, SLX4/Slx4 $4^{\text {S.c. }}$ forms a complex with its interacting partner SLX1/Slx1 $1^{\text {S.c. }}$ and, as previously mentioned, serves as a binding platform and catalytic stimulator for both MUS81-EME1/Mus81-Mms4 $4^{\text {S.c. }}$ and XPF-ERCC1/Rad1-Rad10 S.c. (Figure 4) (reviewed in [11]) [12-15]).

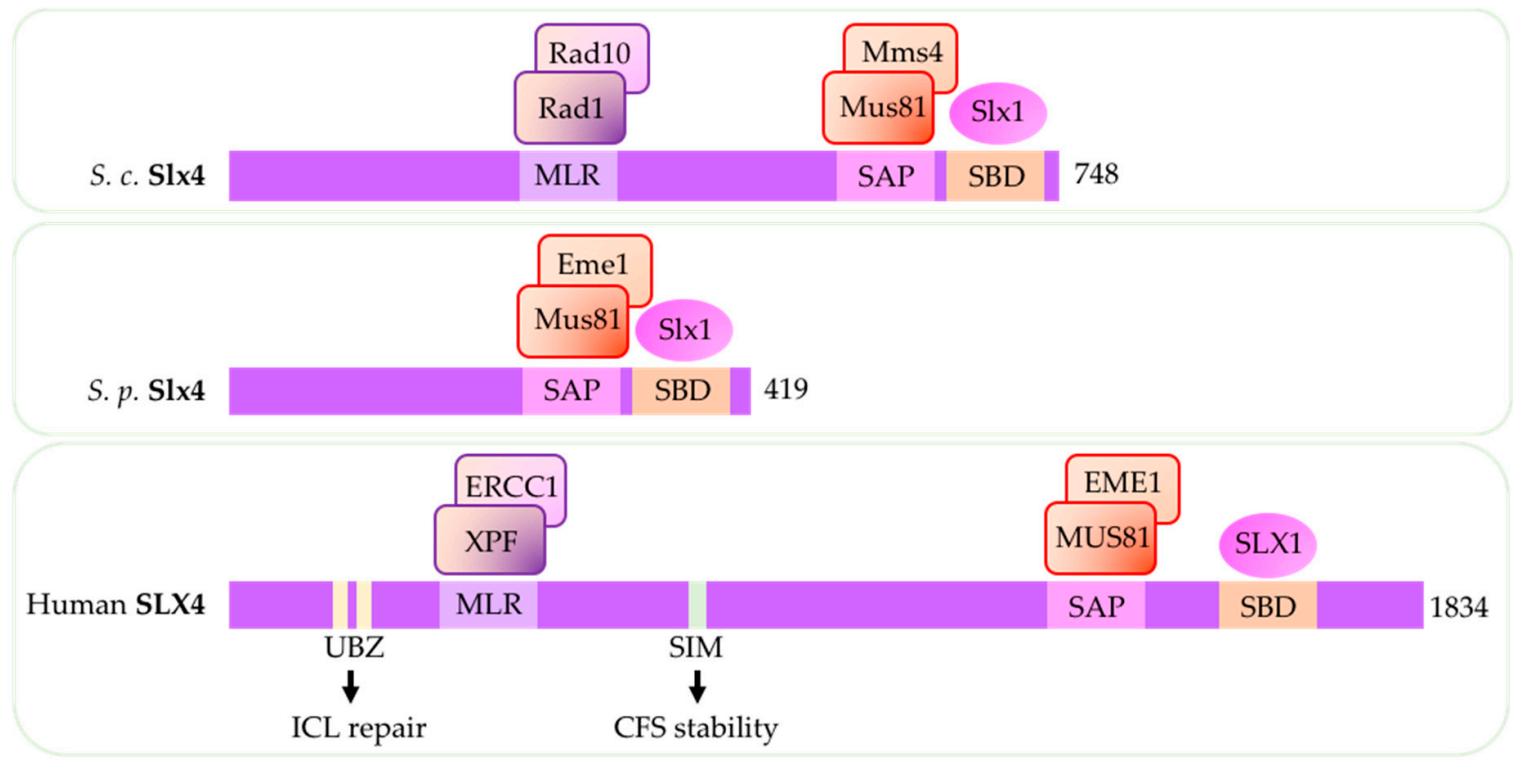

Figure 4. Important domains in SLX4. Across all three species (S.p., S.c., and human), scaffold protein SLX4 have SLX1 binding domain (SBD) and MUS81-EME1 binding region (SAP) [58]. Slx4 $4^{\text {S.c. in }}$ budding yeast and SLX4 in human cells also have XPF-ERCC1 interacting region MLR. Slx4 $4^{\text {S.p. }}$ in fission yeast lack MLR. SLX4 in human cells have UBZ (ubiquitin-binding zinc finger domain) and SIM (SUMO-interaction motif )motifs that contributes to its recruitment and activity $[135,136]$. (SBD: SLX1 binding domain; SAP: SAF-A/B, Acinus and PIAS domain that interacts with MUS81-EME1; MLR: MEI9XPF-interaction-like region that interacts with XPF-ERCC1; ICL: interstrand crosslink; CFS: common fragile site) (S.c.: S. cerevisiae; S.p.: S. pombe). 
In budding yeast, upon replication stress, Slx $4^{\text {S.c. }}$ forms a complex with another scaffold protein $\mathrm{Rtt}_{107^{\text {S.c. }}}$ (PTIP H.s. $)$ and DNA replication initiation protein Dpb11 ${ }^{\text {S.c. }}\left(\mathrm{TOPBP}^{\text {H.s. }}\right.$ ) and associates with Mus81-Mms4 $4^{\text {S.c. }}$ behind replication forks after $\mathrm{Cdc} 28^{\text {S.c. }}$-and $\mathrm{Cdc} 5^{\text {S.c. }}$-mediated phosphorylation of Mms4 ${ }^{\text {S.c. }}$ [16-20]. In Mus81 $1^{\text {S.c. }}$-deficient cells, Slx4 $4^{\text {S.c. }}$ play a critical role supporting replication-coupled ICL repair by Rad1-Rad10 ${ }^{\text {S.C. }}$ [137]. In contrast to budding yeast, Slx4 $4^{\text {S.p. }}$ in fission yeast lacks the XPF-interacting region (Figure 4 ) and does not appear to affect Rad16 ${ }^{\text {S.p. }}$ as Slx $4^{\text {S.p. }}$. deletion has no sensitivity to UV or MMS and no synthetic growth defects with Rad16 ${ }^{\text {S.p. }}$ mutation [21].

In human cells, increased association of MUS81-EME1 with the scaffold protein SLX4 contributes to MUS81-dependent processing of DNA secondary structures [12]. SLX4 deletion reduces MUS81-dependent formation of DSBs that occur after WEE1 inhibition [62,67]. SLX4 is phosphorylated by CDK1 in late G2 and M phase and interacts with MUS81-EME1 complex and SLX1, forming stable SLX-MUS complex (reviewed in [49,62]. SLX4 recruitment to chromatin and SLX4-mediated sister chromatid resolution requires TOPBP1 [138]. In addition to recruiting MUS81-EME1 and XPF-ERCC1, nuclease activity of SLX4 is important for processing telomeric structures and oppose aberrant telomere synthesis observed in cancers (reviewed in [139]) [140,141]. SLX4 also suppresses chromatin association with another SSE, GEN1(Yen1), in the absence of MUS81 and prevent DSBs after pathological replication stress [142]. Human SLX4 has ubiquitin-binding zinc finger (UBZ) motif and SUMO-interaction motif (SIMs) (Figure 4) $[135,136]$. The UBZ motif is required for SLX4 recruitment to sites of replication-dependent ICL repair while the SIMs is required for the function of SLX4 during replication stress and in suppressing CFS instability [143,144].

\section{Other Structure-Specific Endonuclease in Replication Stress}

Although MUS81-EME1 and XPF-ERCC1, along with the scaffold protein SLX4, are the most well-characterized SSEs to be responsible for processing replication intermediates, a few other SSEs have been noted to be important in dealing with replication stress.

\subsection{Rad2 (Schizosaccharomyces pombe)/Rad27 (Saccharomyces cerevisiae)/FEN1 (Flap Endonuclease 1) (Human)}

Flap endonuclease 1 (FEN1 in human, $\operatorname{Rad} 2^{\text {S.p. }}$ in fission yeast, $\operatorname{Rad} 27^{\text {S.c. }}$ in budding yeast) has an important role of removing 5 ä flaps that form during Okazaki fragment maturation via its interaction with DNA processivity factor PCNA (Table 1) (reviewed in [115]). FEN1 is also involved in processing DNA secondary structures during replication fork impediment, especially in rDNA and telomeres [145-147]. This process requires FEN1 to undergo SUMOylation and subsequent interaction with the PCNA-like Rad9-Rad1-Hus1 complex [116,124]. FEN1 and MUS81 associate with each other and collaborate in removing various aberrant DNA structures, including regressed replication fork substrates [117-119]. FEN1 removes the 5 ä-flap after MUS81 processes DNA junction structures (reviewed in [78]) [86]. This process requires FEN1 to be stimulated by the helicase WRN (Werner syndrome ATP-dependent RecQ like helicase) [120-122]. This activity is especially critical for the fork restart at telomeres [146]. Regulation of FEN1 activity is important in maintaining genome stability as overexpression of FEN1 is associated with poor prognosis in various cancers [137]. FEN1 overexpression results in impediment in replication fork progression, mid-S phase arrest, and hypersensitivity to DNA damaging agents [137].

\subsection{Fan1 (Schizosaccharomyces pombe)/Absent in Saccharomyces cerevisiae/FAN1 (Fanconi-Associated Nuclease I) (Human)}

FAN1 (Fanconi-associated nuclease I) is another structure-dependent endonuclease that plays a critical role in ICLs repair (reviewed in [148]) and in promoting replication fork progression in response to replication stress induced by agents such as HU and MMS $[123,149]$. There is no apparent FAN1 homolog in the budding yeast. FAN1 exhibits endonuclease activity toward $5 \backsim$ ä flaps and has $5 \sim$ ä-3 3 ä exonuclease activity [150]. A recent study suggests that FAN1 dimerizes to have optimal cleavage of a 
long 5 ä flap strand [151]. FAN1 nuclease activity at stalled replication forks is tightly regulated as FAN1 activity is needed for fork restart but excessive activity can result in fork degradation (reviewed in [148]) [149]. Fan1 ${ }^{-/-}$mice have repeat expansions in brain and other somatic tissues, demonstrating that FAN1 activity contributes to the maintenance of genome integrity [152]. Like SLX4, FAN1 has a UBZ motif which allows its association with monoubiquitylated FANCD2 and subsequent recruitment to at replication forks (Table 1) [123]. FAN1 can also be recruited to aphidicolin-stalled replication forks via FANCD2-BLM (Fanconi anemia group D2 protein- Bloom's helicase) complex independent of the UBZ domain [149]. FAN1 also contains PCNA interacting peptide (PIP) motif that allows its association with ubiquitylated PCNA accumulated at stalled replication forks [124].

\subsection{Absent in S. pombe/Yen1/GEN1}

Yen1 ${ }^{\text {S.c. }}$ (crossover junction endodeoxyribonuclease 1) in budding yeast and GEN1 (XPG-like endonuclease 1) in humans are SSEs that belong to the XPG/Rad2 family and define another Holliday junction resolvase that can process replication intermediates (reviewed in [153]). In MUS81-deficient human cells, GEN1 can induce DSB following replication stress which is opposed by the presence of SLX4 [142]. In budding yeast, Yen1 $1^{\text {S.c. }}$ is phosphorylated by Cdc28 $8^{\text {S.c. }}$ at G1/S transition which inactivates its nuclear localization signal (NLS), ensuring Yen1 ${ }^{\text {S.c. }}$ stays in the cytoplasm until anaphase (Table 1) [22-24]. Cdc14 ${ }^{\text {S.c. }}$ dephosphorylates Yen1 ${ }^{\text {S.c. }}$ at anaphase, allowing it to enter the nucleus [23]. In human cells, GEN1 contains a nuclear export signal (NES) and cannot access chromatin until the nuclear envelope is broken down during mitosis [25]. It is absent in fission yeast which may explain why meiosis is highly dependent on Mus81-Eme1 in fission yeast (reviewed in [26]).

It is important to remember that there may be nucleases that have not been previously implicated in replication stress that may also contribute to processing replication intermediates. For example, a recent study suggests that Artemis, a nuclease involved in non-homologous DNA end-joining (NHEJ) (reviewed in [154]), contributes to processing stalled DNA replication forks and prevent chromosomal segregation defect during mitosis [10]. Artemis is not present in yeast.

\section{Concluding Remarks}

We have summarized findings showing how SSEs, MUS81 and XPF in particular, are controlled during cell cycle and replication stress (Figure 5). Cell cycle kinase, replication checkpoint kinase, and the various interacting partners as well as inducers of post-translational and epigenetic modifiers work in consortium, allowing cells to quickly respond to replication stress but limit extraneous DNA damage. Teasing out the regulatory networks that control SSE activities and how they communicate with each other can help gain a more comprehensive understanding of how SSEs contribute to cancer. On one hand, SSEs are needed to maintain genome stability but on the other hand, DNA cleavage by SSEs can contribute to inducing DNA damage and chromosome rearrangement. For example, Mus 81 cleavage of the displacement loop (D-loop), the initial recombination intermediate that form in broken replication forks, limits mutagenic template switches that propels genome instability in cancers [155].

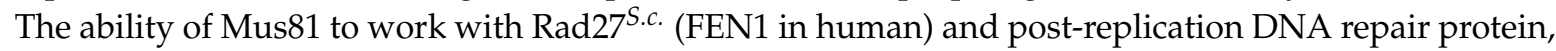
Rad18 $8^{\text {S.c. }}$, to suppress repeat-mediated chromosomal rearrangements has been suggested to inhibit large inverted duplications of chromosomal segments observed frequently in cancers [156]. In other contexts, Mus81 activity can contribute to survivability of cancer cells. For instance, Mus81-mediated resolution of toxic intermediates resulting from break-induced replication in the absence of Srs2 ${ }^{\text {S.c. }}$ helicase increases cell viability [157].

There is somewhat conflicting evidence on how SSEs influence chemotherapy response. In various types of cancer cells, downregulation of XPF or MUS81 increases sensitivity to chemotherapeutic drugs cells via CHK1 pathway activation or stimulation of apoptosis $[63,158,159]$. However, there is also evidence that cytosolic DNA generated by MUS81 in prostate cancers stimulate immune response, potentially contributing to host rejection of cancer cells [160]. More in-depth understanding of how SSE 
activities are controlled will help formulate better predictions about their involvement in carcinogenesis and in patient-response to anti-cancer therapeutics.

Some of critical questions regarding SSEs still need to be addressed:

- How do regulation and roles of MUS81 and XPF differ between mitosis and meiosis?

- What molecular brakes exist that allow SSEs to process aberrant replication structures without deleterious DNA breakage?

- How does chromatin structure or components influence SSE recruitment and activity?

- How do SSEs coordinate or communicate with other SSEs and other DNA-remodeling enzymes?

- Do SSE activities contribute to checkpoint activation and cell cycle arrest? If so, what is the molecular mechanism?

Exploring these questions and other uncharacterized aspects of SSEs will garner exciting and important insights needed to integrate our understanding of the replication process, genome stability and the cell cycle.

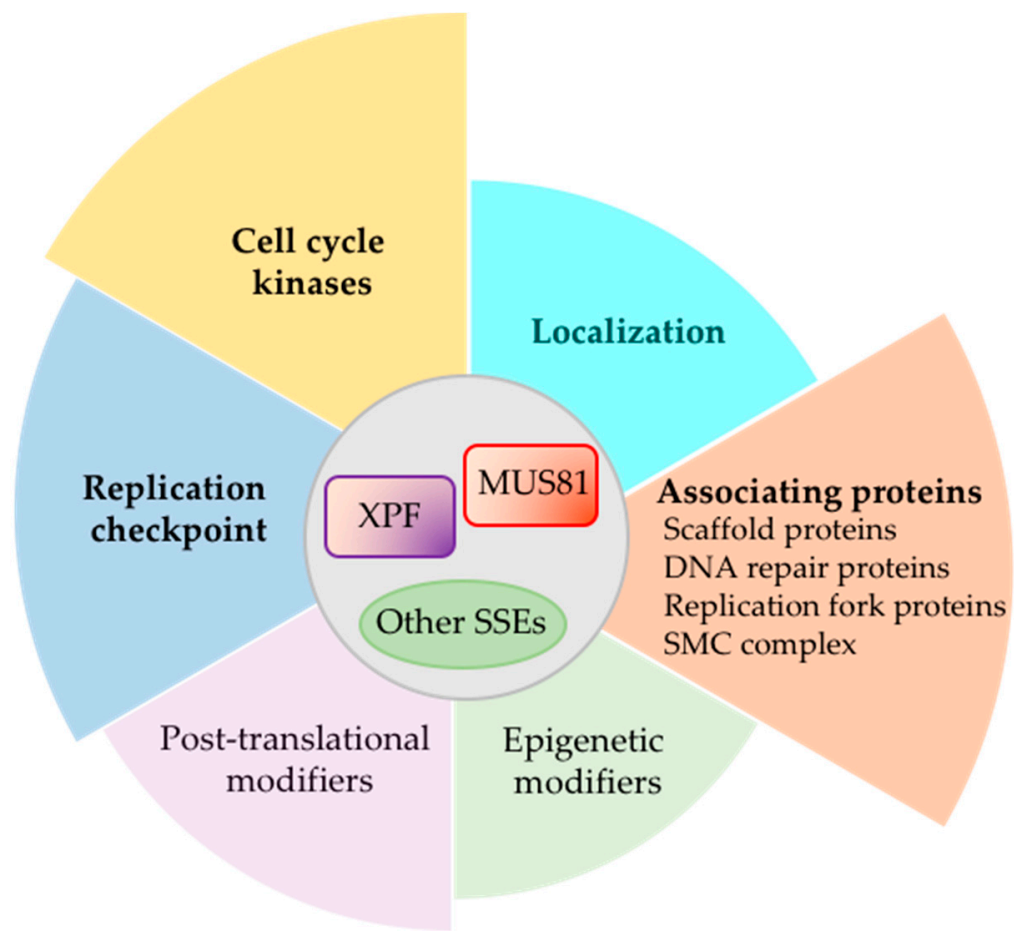

Figure 5. Summary of types of regulation of SSEs (MUS81 and XPF in particular) involved in resolving replication intermediates.

Author Contributions: Both authors drafted and revised the manuscript.

Funding: This work was funded by NIH R35-GM118109

Acknowledgments: We thank the members of the Forsburg Lab for helpful discussions.

Conflicts of Interest: The authors declare no conflict of interest.

\section{References}

1. Zeman, M.K.; Cimprich, K.A. Causes and consequences of replication stress. Nat. Cell Biol. 2014, 16, 2-9. [CrossRef]

2. Técher, H.; Koundrioukoff, S.; Nicolas, A.; Debatisse, M. The impact of replication stress on replication dynamics and DNA damage in vertebrate cells. Nat. Rev. Genet. 2017, 18, 535-550. [CrossRef] 
3. Mirkin, E.V.; Mirkin, S.M. Replication Fork Stalling at Natural Impediments. Microbiol. Mol. Biol. Rev. 2007, 71, 13-35. [CrossRef] [PubMed]

4. Magdalou, I.; Lopez, B.S.; Pasero, P.; Lambert, S.A.E. The causes of replication stress and their consequences on genome stability and cell fate. Semin. Cell Dev. Biol. 2014, 30, 154-164. [CrossRef]

5. Tubbs, A.; Nussenzweig, A. Endogenous DNA Damage as a Source of Genomic Instability in Cancer. Cell 2017, 168, 644-656. [CrossRef]

6. Macheret, M.; Halazonetis, T.D. DNA Replication Stress as a Hallmark of Cancer. Annu. Rev. Pathol. Mech. Dis. 2015, 10, 425-448. [CrossRef] [PubMed]

7. Blumenfeld, B.; Ben-Zimra, M.; Simon, I. Perturbations in the replication program contribute to genomic instability in cancer. Int. J. Mol. Sci. 2017, 18. [CrossRef] [PubMed]

8. Dehé, P.M.; Gaillard, P.H.L. Control of structure-specific endonucleases to maintain genome stability. Nat. Rev. Mol. Cell Biol. 2017, 18, 315-330. [CrossRef]

9. Ait Saada, A.; Lambert, S.A.E.; Carr, A.M. Preserving replication fork integrity and competence via the homologous recombination pathway. DNA Repair (Amst). 2018, 71, 135-147. [CrossRef]

10. Bétous, R.; Goullet de Rugy, T.; Pelegrini, A.L.; Queille, S.; de Villartay, J.P.; Hoffmann, J.S. DNA replication stress triggers Rapid DNA Replication Fork Breakage by Artemis and XPF. PLoS Genet. 2018, 14, 1-16. [CrossRef]

11. Kim, Y. Nuclease Delivery: Versatile Functions of SLX4/FANCP in Genome Maintenance. Mol. Cells 2014, 37, 569-574. [CrossRef] [PubMed]

12. Muñoz, I.M.; Hain, K.; Déclais, A.C.; Gardiner, M.; Toh, G.W.; Sanchez-Pulido, L.; Heuckmann, J.M.; Toth, R.; Macartney, T.; Eppink, B.; Kanaar, R.; Ponting, C.P.; Lilley, D.M.J.; Rouse, J. Coordination of Structure-Specific Nucleases by Human SLX4/BTBD12 Is Required for DNA Repair. Mol. Cell 2009, 35, 116-127. [CrossRef] [PubMed]

13. Andersen, S.L.; Bergstralh, D.T.; Kohl, K.P.; LaRocque, J.R.; Moore, C.B.; Sekelsky, J. Drosophila MUS312 and the Vertebrate Ortholog BTBD12 Interact with DNA Structure-Specific Endonucleases in DNA Repair and Recombination. Mol. Cell 2009, 35, 128-135. [CrossRef] [PubMed]

14. Fekairi, S.; Scaglione, S.; Chahwan, C.; Taylor, E.R.; Tissier, A.; Coulon, S.; Dong, M.Q.; Ruse, C.; Yates, J.R.; Russell, P.; Fuchs, R.P.; McGowan, C.H.; Gaillard, P.H.L. Human SLX4 Is a Holliday Junction Resolvase Subunit that Binds Multiple DNA Repair/Recombination Endonucleases. Cell 2009, 138, 78-89. [CrossRef] [PubMed]

15. Svendsen, J.M.; Smogorzewska, A.; Sowa, M.E.; O'Connell, B.C.; Gygi, S.P.; Elledge, S.J.; Harper, J.W. Mammalian BTBD12/SLX4 Assembles A Holliday Junction Resolvase and Is Required for DNA Repair. Cell 2009, 138, 63-77. [CrossRef] [PubMed]

16. Princz, L.N.; Gritenaite, D.; Pfander, B. The Slx4-Dpb11 scaffold complex: Coordinating the response to replication fork stalling in S-phase and the subsequent mitosis. Cell Cycle 2015, 14, 488-494. [CrossRef] [PubMed]

17. Ohouo, P.Y.; Bastos De Oliveira, F.M.; Liu, Y.; Ma, C.J.; Smolka, M.B. DNA-repair scaffolds dampen checkpoint signalling by counteracting the adaptor Rad9. Nature 2013, 493, 120-125. [CrossRef]

18. Balint, A.; Kim, T.; Gallo, D.; Cussiol, J.R.; Bastos de Oliveira, F.M.; Yimit, A.; Ou, J.; Nakato, R.; Gurevich, A.; Shirahige, K.; Smolka, M.B.; Zhang, Z.; Brown, G.W. Assembly of Slx4 signaling complexes behind DNA replication forks. EMBO J. 2015, 34, 2182-2197. [CrossRef] [PubMed]

19. Gritenaite, D.; Princz, L.N.; Szakal, B.; Bantele, S.C.S.; Wendeler, L.; Schilbach, S.; Habermann, B.H.; Matos, J.; Lisby, M.; Branzei, D.; Pfander, B. A cell cycle-regulated Slx4 - Dpb11 complex promotes the resolution of DNA repair intermediates linked to stalled replication. Genes Dev. 2014, 28, 1604-1619. [CrossRef]

20. Cussiol, J.R.; Jablonowski, C.M.; Yimit, A.; Brown, G.W.; Smolka, M.B. Dampening DNA damage checkpoint signalling via coordinated BRCT domain interactions. EMBO J. 2015, 34, e201490834. [CrossRef] [PubMed]

21. Mastro, T.L.; Forsburg, S.L. Increased meiotic crossovers and reduced genome stability in absence of Schizosaccharomyces pombe Rad16 (XPF). Genetics 2014, 198, 1457-1472. [CrossRef] [PubMed]

22. Eissler, C.L.; Mazón, G.; Powers, B.L.; Savinov, S.N.; Symington, L.S.; Hall, M.C. The Cdk/Cdc14 Module Controls Activation of the Yen1 Holliday Junction Resolvase to Promote Genome Stability. Mol. Cell 2014, 54, 80-93. [CrossRef] [PubMed]

23. García-Luis, J.; Clemente-Blanco, A.; Aragón, L.; Machín, F. Cdc14 targets the Holliday junction resolvase Yen1 to the nucleus in early anaphase. Cell Cycle 2014, 13, 1392-1399. [CrossRef] 
24. Blanco, M.G.; Matos, J.; West, S.C. Dual Control of Yen1 Nuclease Activity and Cellular Localization by Cdk and Cdc14 Prevents Genome Instability. Mol. Cell 2014, 54, 94-106. [CrossRef] [PubMed]

25. Chan, Y.W.; West, S.C. Spatial control of the GEN1 Holliday junction resolvase ensures genome stability. Nat. Commun. 2014, 5, 1-11. [CrossRef] [PubMed]

26. Svendsen, J.M.; Harper, J.W. GEN1/Yen1 and the SLX4 complex: Solutions to the problem of Holliday junction resolution. Genes Dev. 2010, 24, 521-536. [CrossRef] [PubMed]

27. Boddy, M.N.; Russell, P. DNA replication checkpoint. Curr. Biol. 2001, 11, R953-R956. [CrossRef]

28. Ciccia, A.; McDonald, N.; West, S.C. Structural and Functional Relationships of the XPF/MUS81 Family of Proteins. Annu. Rev. Biochem. 2008, 77, 259-287. [CrossRef]

29. Boddy, M.N.; Lopez-Girona, A.; Shanahan, P.; Interthal, H.; Heyer, W.D.; Russell, P. Damage tolerance protein Mus81 associates with the FHA1 domain of checkpoint kinase Cds1. Mol. Cell. Biol. 2000, 20, 8758-8766. [CrossRef]

30. Doe, C.L.; Ahn, J.S.; Dixon, J.; Whitby, M.C. Mus81-Eme1 and Rqh1 involvement in processing stalled and collapsed replication forks. J. Biol. Chem. 2002, 277, 32753-32759. [CrossRef]

31. Boddy, M.N.; Gaillard, P.L.; Mcdonald, W.H.; Shanahan, P.; Yates, J.R.; Russell, P.; Jolla, L. Mus81-Eme1 Are Essential Components of a Holliday Junction Resolvase. Cell 2001, 107, 537-548. [CrossRef]

32. Chen, X.B.; Melchionna, R.; Denis, C.M.; Gaillard, P.H.L.; Blasina, A.; Van de Weyer, I.; Boddy, M.N.; Russell, P.; Vialard, J.; McGowan, C.H. Human Mus81-associated endonuclease cleaves Holliday junctions in vitro. Mol. Cell 2001, 8, 1117-1127. [CrossRef]

33. Kaliraman, V.; Mullen, J.R.; Fricke, W.M.; Bastin-shanower, S.A.; Brill, S.J. Functional overlap between Sgs1 Top3 and the Mms4 - Mus81 endonuclease. Genes Dev. 2001, 15, 2730-2740. [CrossRef] [PubMed]

34. Oke, A.; Anderson, C.M.; Yam, P.; Fung, J.C. Controlling Meiotic Recombinational Repair - Specifying the Roles of ZMMs, Sgs1 and Mus81/Mms4 in Crossover Formation. PLoS Genet. 2014, 10. [CrossRef] [PubMed]

35. De Los Santos, T.; Loidl, J.; Larkin, B.; Hollingsworth, N.M. A role for MMS4 in the processing of recombination intermediates during meiosis in Saccharomyces cerevisiae. Genetics 2001, 159, 1511-1525.

36. Roseaulin, L.; Yamada, Y.; Tsutsui, Y.; Russell, P.; Iwasaki, H.; Arcangioli, B. Mus81 is essential for sister chromatid recombination at broken replication forks. EMBO J. 2008, 27, 1378-1387. [CrossRef]

37. Sanchez, A.; Gadaleta, M.C.; Limbo, O.; Russell, P. Lingering single-strand breaks trigger Rad51-independent homology-directed repair of collapsed replication forks in the polynucleotide kinase/phosphatase mutant of fission yeast. PLoS Genet. 2017, 13, 1-20. [CrossRef]

38. Hanada, K.; Budzowska, M.; Davies, S.L.; Van Drunen, E.; Onizawa, H.; Beverloo, H.B.; Maas, A.; Essers, J.; Hickson, I.D.; Kanaar, R. The structure-specific endonuclease Mus81 contributes to replication restart by generating double-strand DNA breaks. Nat. Struct. Mol. Biol. 2007, 14, 1096-1104. [CrossRef]

39. Regairaz, M.; Zhang, Y.W.; Fu, H.; Agama, K.K.; Tata, N.; Agrawal, S.; Aladjem, M.I.; Pommier, Y. Mus81-mediated DNA cleavage resolves replication forks stalled by topoisomerase I-DNA complexes. J. Cell Biol. 2011, 195, 739-749. [CrossRef]

40. Shimura, T.; Torres, M.J.; Martin, M.M.; Rao, V.A.; Pommier, Y.; Katsura, M.; Miyagawa, K.; Aladjem, M.I. Bloom's Syndrome Helicase and Mus81 are Required to Induce Transient Double-strand DNA Breaks in Response to DNA Replication Stress. J. Mol. Biol. 2008, 375, 1152-1164. [CrossRef]

41. Fu, H.; Martin, M.M.; Regairaz, M.; Huang, L.; You, Y.; Lin, C.M.; Ryan, M.; Kim, R.; Shimura, T.; Pommier, Y.; Aladjem, M.I. The DNA repair endonuclease Mus81 facilitates fast DNA replication in the absence of exogenous damage. Nat. Commun. 2015, 6, 6746. [CrossRef] [PubMed]

42. Lemaçon, D.; Jackson, J.; Quinet, A.; Brickner, J.R.; Li, S.; Yazinski, S.; You, Z.; Ira, G.; Zou, L.; Mosammaparast, N.; Vindigni, A. MRE11 and EXO1 nucleases degrade reversed forks and elicit MUS81-dependent fork rescue in BRCA2-deficient cells. Nat. Commun. 2017, 8, 860. [CrossRef] [PubMed]

43. Lai, X.; Broderick, R.; Bergoglio, V.; Zimmer, J.; Badie, S.; Niedzwiedz, W.; Hoffmann, J.S.; Tarsounas, M. MUS81 nuclease activity is essential for replication stress tolerance and chromosome segregation in BRCA2-deficient cells. Nat. Commun. 2017, 8, 15983. [CrossRef] [PubMed]

44. Kai, M.; Boddy, M.N.; Russell, P.; Wang, T.S. Replication checkpoint kinase Cds1 regulates Mus81 to preserve genome integrity during replication stress. Genes Dev. 2005, 19, 919-932. [CrossRef] [PubMed]

45. Morrow, C.A.; Nguyen, M.O.; Fower, A.; Wong, I.N.; Osman, F.; Bryer, C.; Whitby, M.C. Inter-Fork Strand Annealing causes genomic deletions during the termination of DNA replication. Elife 2017, 6, 1-15. [CrossRef] [PubMed] 
46. Neelsen, K.J.; Zanini, I.M.Y.; Herrador, R.; Lopes, M. Oncogenes induce genotoxic stress by mitotic processing of unusual replication intermediates. J. Cell Biol. 2013, 200, 699-708. [CrossRef] [PubMed]

47. Chang, J.H.; Kim, J.J.; Choi, J.M.; Lee, J.H.; Cho, Y. Crystal structure of the Mus81 - Eme1 complex. Genes Dev. 2008, 22, 1093-1106. [CrossRef]

48. Gallo-Fernández, M.; Saugar, I.; Ortiz-Bazán, M.Á.; Vázquez, M.V.; Tercero, J.A. Cell cycle-dependent regulation of the nuclease activity of Mus81-Eme1/Mms4. Nucleic Acids Res. 2012, 40, 8325-8335. [CrossRef] [PubMed]

49. Matos, J.; West, S.C. Holliday junction resolution: Regulation in space and time. DNA Repair (Amst). 2014, 19, 176-181. [CrossRef] [PubMed]

50. Szakal, B.; Branzei, D. Premature Cdk1/Cdc5/Mus81 pathway activation induces aberrant replication and deleterious crossover. EMBO J. 2013, 32, 1155-1167. [CrossRef]

51. Saugar, I.; Vázquez, M.V.; Gallo-Fernández, M.; Ortiz-Bazán, M.Á.; Segurado, M.; Calzada, A.; Tercero, J.A. Temporal regulation of the Mus81-Mms4 endonuclease ensures cell survival under conditions of DNA damage. Nucleic Acids Res. 2013, 41, 8943-8958. [CrossRef] [PubMed]

52. Princz, L.N.; Wild, P.; Bittmann, J.; Aguado, F.J.; Blanco, M.G.; Matos, J.; Pfander, B. Dbf4-dependent kinase and the Rtt107 scaffold promote Mus81-Mms4 resolvase activation during mitosis. EMBO J. 2017, 36, 664-678. [CrossRef] [PubMed]

53. Dehé, P.M.; Coulon, S.; Scaglione, S.; Shanahan, P.; Takedachi, A.; Wohlschlegel, J.A.; Yates, J.R.; Llorente, B.; Russell, P.; Gaillard, P.H.L. Regulation of Mus81-Eme1 Holliday junction resolvase in response to DNA damage. Nat. Struct. Mol. Biol. 2013, 20, 598-603. [CrossRef]

54. Sabatinos, S.A.; Ranatunga, N.S.; Yuan, J.; Green, M.D.; Forsburg, S.L.; Solomon, M.J. Replication stress in early $S$ phase generates apparent micronuclei and chromosome rearrangement in fission yeast. Mol. Biol. Cell 2015, 26, 3439-3450. [CrossRef]

55. Pepe, A.; West, S.C. MUS81-EME2 promotes replication fork restart. Cell Rep. 2014, 7, 1048-1055. [CrossRef] [PubMed]

56. Pfander, B.; Matos, J. Control of Mus81 nuclease during the cell cycle. FEBS Lett. 2017, 591, $2048-2056$. [CrossRef] [PubMed]

57. Xing, M.; Wang, X.; Palmai-Pallag, T.; Shen, H.; Helleday, T.; Hickson, I.D.; Ying, S. Acute MUS81 depletion leads to replication fork slowing and a constitutive DNA damage response. Oncotarget 2015, 6, 37638-37646. [CrossRef]

58. Wyatt, H.D.M.; Sarbajna, S.; Matos, J.; West, S.C. Coordinated actions of SLX1-SLX4 and MUS81-EME1 for holliday junction resolution in human cells. Mol. Cell 2013, 52, 234-247. [CrossRef]

59. Castor, D.; Nair, N.; Déclais, A.C.; Lachaud, C.; Toth, R.; Macartney, T.J.; Lilley, D.M.J.; Arthur, J.S.C.; Rouse, J. Cooperative control of holliday junction resolution and DNA Repair by the SLX1 and MUS81-EME1 nucleases. Mol. Cell 2013, 52, 221-233. [CrossRef]

60. Palma, A.; Pugliese, G.M.; Murfuni, I.; Marabitti, V.; Malacaria, E.; Rinalducci, S.; Minoprio, A.; Sanchez, M.; Mazzei, F.; Zolla, L.; Franchitto, A.; Pichierri, P. Phosphorylation by CK2 regulates MUS81/EME1 in mitosis and after replication stress. Nucleic Acids Res. 2018, 46, 5109-5124. [CrossRef]

61. Domínguez-Kelly, R.; Martín, Y.; Koundrioukoff, S.; Tanenbaum, M.E.; Smits, V.A.J.; Medema, R.H.; Debatisse, M.; Freire, R. Wee1 controls genomic stability during replication by regulating the Mus81-Eme1 endonuclease. J. Cell Biol. 2011, 194, 567-579. [CrossRef] [PubMed]

62. Duda, H.; Arter, M.; Gloggnitzer, J.; Teloni, F.; Wild, P.; Blanco, M.G.; Altmeyer, M.; Matos, J. A Mechanism for Controlled Breakage of Underreplicated Chromosomes during Mitosis. Dev. Cell 2016, 39, 740-755. [CrossRef]

63. Szmyd, R.; Niska-blakie, J.; Diril, M.K.; Nunes, P.R.; Tzelepis, K.; Lacroix, A.; Van Hul, N.; Joao, L.D.; Oliver, M.; Xavier, D. Premature activation of Cdk1 leads to mitotic events in S phase and embryonic lethality. Oncogene 2018. [CrossRef]

64. Xu, Y.; Ning, S.; Wei, Z.; Xu, R.; Xu, X.; Xing, M.; Guo, R.; Xu, D. 53BP1 and BRCA1 control pathway choice for stalled replication restart. Elife 2017, 6, 1-24. [CrossRef] [PubMed]

65. Di Marco, S.; Hasanova, Z.; Kanagaraj, R.; Chappidi, N.; Altmannova, V.; Menon, S.; Sedlackova, H.; Langhoff, J.; Surendranath, K.; Hühn, D.; Bhowmick, R.; Marini, V.; Ferrari, S.; Hickson, I.D.; Krejci, L.; Janscak, P. RECQ5 Helicase Cooperates with MUS81 Endonuclease in Processing Stalled Replication Forks at Common Fragile Sites during Mitosis. Mol. Cell 2017, 66, 658-671. [CrossRef] 
66. Beck, H.; Nähse, V.; Larsen, M.S.Y.; Groth, P.; Clancy, T.; Lees, M.; Jørgensen, M.; Helleday, T.; Syljuåsen, R.G.; Sørensen, C.S. Regulators of cyclin-dependent kinases are crucial for maintaining genome integrity in $S$ phase. J. Cell Biol. 2010, 188, 629-638. [CrossRef]

67. Beck, H.; Nahse-Kumpf, V.; Larsen, M.S.Y.; O’Hanlon, K.A.; Patzke, S.; Holmberg, C.; Mejlvang, J.; Groth, A.; Nielsen, O.; Syljuasen, R.G.; Sorensen, C.S. Cyclin-Dependent Kinase Suppression by WEE1 Kinase Protects the Genome through Control of Replication Initiation and Nucleotide Consumption. Mol. Cell. Biol. 2012, 32, 4226-4236. [CrossRef] [PubMed]

68. Forment, J.V.; Blasius, M.; Guerini, I.; Jackson, S.P. Structure-specific DNA endonuclease Mus81/Eme1 generates DNA damage caused by Chk1 inactivation. PLoS ONE 2011, 6, e23517. [CrossRef]

69. Murfuni, I.; Basile, G.; Subramanyam, S.; Malacaria, E.; Bignami, M.; Spies, M.; Franchitto, A.; Pichierri, P. Survival of the Replication Checkpoint Deficient Cells Requires MUS81-RAD52 Function. PLoS Genet. 2013, 9, e1003910. [CrossRef]

70. Técher, H.; Koundrioukoff, S.; Carignon, S.; Wilhelm, T.; Millot, G.A.; Lopez, B.S.; Brison, O.; Debatisse, M. Signaling from Mus81-Eme2-Dependent DNA Damage Elicited by Chk1 Deficiency Modulates Replication Fork Speed and Origin Usage. Cell Rep. 2016, 14, 1114-1127. [CrossRef]

71. Fragkos, M.; Naim, V. Rescue from replication stress during mitosis. Cell Cycle 2017, 16, 613-633. [CrossRef]

72. Naim, V.; Wilhelm, T.; Debatisse, M.; Rosselli, F. ERCC1 and MUS81-EME1 promote sister chromatid separation by processing late replication intermediates at common fragile sites during mitosis. Nat. Cell Biol. 2013, 15, 1008-1015. [CrossRef] [PubMed]

73. Ying, S.; Minocherhomji, S.; Chan, K.L.; Palmai-Pallag, T.; Chu, W.K.; Wass, T.; Mankouri, H.W.; Liu, Y.; Hickson, I.D. MUS81 promotes common fragile site expression. Nat. Cell Biol. 2013, 15, 1001-1007. [CrossRef] [PubMed]

74. Chaudhury, I.; Koepp, D.M. Degradation of Mrc1 promotes recombination-mediated restart of stalled replication forks. Nucleic Acids Res. 2017, 45, 2558-2570. [CrossRef]

75. Sebesta, M.; Urulangodi, M.; Stefanovie, B.; Szakal, B.; Pacesa, M.; Lisby, M.; Branzei, D.; Krejci, L. Esc2 promotes Mus81 complex-activity via its SUMO-like and DNA binding domains. Nucleic Acids Res. 2017, 45, 215-230. [CrossRef] [PubMed]

76. Froget, B.; Blaisonneau, J.; Lambert, S.; Baldacci, G. Cleavage of Stalled Forks by Fission Yeast Mus81/Eme1 in Absence of DNA Replication Checkpoint. Mol. Biol. Cell 2008, 19, 445-456. [CrossRef]

77. Feijoo, C.; Hall-Jackson, C.; Wu, R.; Jenkins, D.; Leitch, J.; Gilbert, D.M.; Smythe, C. Activation of mammalian Chk1 during DNA replication arrest: A role for Chk1 in the intra-S phase checkpoint monitoring replication origin firing. J. Cell Biol. 2001, 154, 913-923. [CrossRef]

78. Kai, M.; Wang, T.S.F. Checkpoint responses to replication stalling: Inducing tolerance and preventing mutagenesis. Mutat. Res. 2003, 532, 59-73. [CrossRef] [PubMed]

79. Rhind, N.; Russell, P. Chk1 and Cds1: Linchpins of the DNA damage and replication checkpoint pathways. J. Cell Sci. 2000, 113, 3889-3896.

80. Mcgowan, C.H. Checking in on Cds1 (Chk2): A checkpoint kinase and tumor suppressor. BioEssays 2002, 24, 502-511. [CrossRef]

81. Xu, Y.; Davenport, M.; Kelly, T.J. Two-stage mechanism for activation of the DNA replication checkpoint kinase Cds1 in fission yeast. Genes Dev. 2006, 20, 990-1003. [CrossRef] [PubMed]

82. Miyabe, I.; Morishita, T.; Shinagawa, H.; Carr, A.M. Schizosaccharomyces pombe Cds1 Chk2 regulates homologous recombination at stalled replication forks through the phosphorylation of recombination protein Rad60. J. Cell Sci. 2009, 122, 3638-3643. [CrossRef] [PubMed]

83. Boddy, M.N.; Shanahan, P.; McDonald, W.H.; Lopez-Girona, A.; Noguchi, E.; Yates, J.R., III; Russell, P. Replication checkpoint kinase Cds1 regulates recombinational repair protein Rad60. Mol. Cell. Biol. 2003, 23, 5939-5946. [CrossRef] [PubMed]

84. Lv, J.; Qian, Y.; Ni, X.; Xu, X.; Dong, X. Feedback regulation of methyl methanesulfonate and ultraviolet-sensitive gene clone 81 via ATM/Chk2 pathway contributes to the resistance of MCF-7 breast cancer cells to cisplatin. Tumor Biol. 2017, 39. [CrossRef]

85. Branzei, D.; Foiani, M. The DNA damage response during DNA replication. Curr. Opin. Cell Biol. 2005, 17, 568-575. [CrossRef] [PubMed]

86. Liu, V.F.; Bhaumik, D.; Wang, T.S. Mutator phenotype induced by aberrant replication. Mol. Cell. Biol. 1999, 19, 1126-1135. [CrossRef] [PubMed] 
87. Kim, S.M.; Huberman, J.A. Regulation of replication timing in fission yeast. EMBO J. 2001, 20, 6115-6126. [CrossRef]

88. Shirahige, K.; Hori, Y.; Shiraishi, K.; Yamashita, M.; Takahashi, K.; Obuse, C.; Tsurimoto, T.; Yoshikawa, H. Regulation of DNA-replication origins during cell-cycle progression. Nature 1998, 395, 618-621. [CrossRef] [PubMed]

89. Santocanale, C.; Diffley, J.F.X. A Mec1-and Rad53-dependent checkpoint controls late-firing origins of DNA replication. Nature 1998, 395, 615-618. [CrossRef]

90. Rossi, S.E.; Ajazi, A.; Carotenuto, W.; Foiani, M.; Giannattasio, M. Rad53-Mediated Regulation of Rrm3 and Pif1 DNA Helicases Contributes to Prevention of Aberrant Fork Transitions under Replication Stress. Cell Rep. 2015, 13, 80-92. [CrossRef]

91. Lucca, C.; Vanoli, F.; Cotta-Ramusino, C.; Pellicioli, A.; Liberi, G.; Haber, J.; Foiani, M. Checkpoint-mediated control of replisome-fork association and signalling in response to replication pausing. Oncogene 2004, 23, 1206-1213. [CrossRef] [PubMed]

92. Sun, Z.; Hsiao, J.; Fay, D.S.; Stern, D.F. Rad53 FHA domain associated with phosphorylated Rad9 in the DNA damage checkpoint. Science 1998, 281, 272-274. [CrossRef]

93. Willis, N.; Rhind, N. Mus81, Rhp51(Rad51), and Rqh1 Form an Epistatic Pathway Required for the S-Phase DNA Damage Checkpoint. Mol. Cell. Biol. 2010, 82, 327-331. [CrossRef] [PubMed]

94. Phung, H.T.T.; Nguyen, H.L.H.; Vo, S.T.; Nguyen, D.H.; Le, M. Van Saccharomyces cerevisiae Mus81-Mms4 and Rad52 can cooperate in the resolution of recombination intermediates. Yeast 2018, 543-553. [CrossRef] [PubMed]

95. Sotiriou, S.K.; Kamileri, I.; Lugli, N.; Evangelou, K.; Da-Ré, C.; Huber, F.; Padayachy, L.; Tardy, S.; Nicati, N.L.; Barriot, S.; Ochs, F.; Lukas, C.; Lukas, J.; Gorgoulis, V.G.; Scapozza, L.; Halazonetis, T.D. Mammalian RAD52 Functions in Break-Induced Replication Repair of Collapsed DNA Replication Forks. Mol. Cell 2016, 64, 1127-1134. [CrossRef]

96. Bhowmick, R.; Minocherhomji, S.; Hickson, I.D. RAD52 Facilitates Mitotic DNA Synthesis Following Replication Stress. Mol. Cell 2016, 64, 1117-1126. [CrossRef] [PubMed]

97. Sisakova, A.; Altmannova, V.; Sebesta, M.; Krejci, L. Role of PCNA and RFC in promoting Mus81-complex activity. BMC Biol. 2017, 15, 1-17. [CrossRef] [PubMed]

98. Zhang, J.; Walter, J.C. Mechanism and regulation of incisions during DNA interstrand cross-link repair. DNA Repair (Amst). 2014, 19, 135-142. [CrossRef]

99. Wehrkamp-Richter, S.; Hyppa, R.W.; Prudden, J.; Smith, G.R.; Boddy, M.N. Meiotic DNA joint molecule resolution depends on Nse5-Nse6 of the Smc5-Smc6 holocomplex. Nucleic Acids Res. 2012, 40, 9633-9646. [CrossRef]

100. Copsey, A.; Tang, S.; Jordan, P.W.; Blitzblau, H.G.; Newcombe, S.; Chan, A.C.; Newnham, L.; Li, Z.; Gray, S.; Herbert, A.D.; Arumugam, P.; Hochwagen, A.; Hunter, N.; Hoffmann, E. Smc5 / 6 Coordinates Formation and Resolution of Joint Molecules with Chromosome Morphology to Ensure Meiotic Divisions. PLoS Genet. 2013, 9. [CrossRef]

101. Minocherhomji, S.; Ying, S.; Bjerregaard, V.A.; Bursomanno, S.; Aleliunaite, A.; Wu, W.; Mankouri, H.W.; Shen, H.; Liu, Y.; Hickson, I.D. Replication stress activates DNA repair synthesis in mitosis. Nature 2015, 528, 286-290. [CrossRef] [PubMed]

102. Sanyal, S.; Molnarova, L.; Richterova, J.; Huraiova, B.; Benko, Z.; Polakova, S.; Cipakova, I.; Sevcovicova, A.; Gaplovska-Kysela, K.; Mechtler, K.; Cipak, L.; Gregan, J. Mutations that prevent methylation of cohesin render sensitivity to DNA damage in S. pombe. J. Cell Sci. 2018, 131, jcs214924. [CrossRef] [PubMed]

103. Gao, H.; Chen, X.B.; McGowan, C.H. Mus81 Endonuclease Localizes to Nucleoli and to Regions of DNA Damage in Human S-phase Cells. Mol. Biol. Cell 2003, 14, 4826-4834. [CrossRef] [PubMed]

104. Saugar, I.; Jiménez-Martín, A.; Tercero, J.A. Subnuclear Relocalization of Structure-Specific Endonucleases in Response to DNA Damage. Cell Rep. 2017, 20, 1553-1562. [CrossRef] [PubMed]

105. Hu, L.; Yang, F.; Lu, L.; Dai, W. Arsenic-induced sumoylation of Mus81 is involved in regulating genomic stability. Cell Cycle 2017, 16, 802-811. [CrossRef]

106. Rondinelli, B.; Gogola, E.; Yücel, H.; Duarte, A.A.; Van De Ven, M.; Van Der Sluijs, R.; Konstantinopoulos, P.A.; Jonkers, J.; Ceccaldi, R.; Rottenberg, S.; D'Andrea, A.D. EZH2 promotes degradation of stalled replication forks by recruiting MUS81 through histone H3 trimethylation. Nat. Cell Biol. 2017, 19, 1371-1378. [CrossRef] 
107. Liang, C.C.; Zhan, B.; Yoshikawa, Y.; Haas, W.; Gygi, S.P.; Cohn, M.A. UHRF1 Is a sensor for DNA interstrand crosslinks and recruits FANCD2 to initiate the Fanconi Anemia pathway. Cell Rep. 2015, 10, 1947-1957. [CrossRef] [PubMed]

108. Tian, Y.; Paramasivam, M.; Ghosal, G.; Chen, D.; Shen, X.; Huang, Y.; Akhter, S.; Legerski, R.; Chen, J.; Seidman, M.M.; Qin, J.; Li, L. UHRF1 contributes to DNA damage repair as a lesion recognition factor and nuclease scaffold. Cell Rep. 2015, 10, 1958-1967. [CrossRef]

109. Guzder, S.N.; Sommers, C.H.; Prakash, L.; Prakash, S. Complex formation with damage recognition protein Rad14 is essential for Saccharomyces cerevisiae Rad1-Rad10 nuclease to perform its function in nucleotide excision repair in vivo. Mol. Cell. Biol. 2006, 26, 1135-1141. [CrossRef] [PubMed]

110. De Laat, W.L.; Appeldoorn, E.; Sugasawa, K.; Weterings, E.; Jaspers, N.G.J.; Hoeijmakers, J.H.J. DNA-binding polarity of human replication protein A positions nucleases in nucleotide excision repair. Genes Dev. 1998, 12, 2598-2609. [CrossRef] [PubMed]

111. Abdullah, U.B.; McGouran, J.F.; Brolih, S.; Ptchelkine, D.; El-Sagheer, A.H.; Brown, T.; McHugh, P.J. RPA activates the XPF-ERCC1 endonuclease to initiate processing of DNA interstrand crosslinks. EMBO J. 2017, 36, 2047-2060. [CrossRef]

112. Motycka, T.A.; Bessho, T.; Post, S.M.; Sung, P.; Tomkinson, A.E. Physical and Functional Interaction between the XPF/ERCC1 Endonuclease and hRad52. J. Biol. Chem. 2004, 279, 13634-13639. [CrossRef] [PubMed]

113. Zhang, J.M.; Liu, X.M.; Ding, Y.H.; Xiong, L.Y.; Ren, J.Y.; Zhou, Z.X.; Wang, H.T.; Zhang, M.J.; Yu, Y.; Dong, M.Q.; Du, L.L. Fission Yeast Pxd1 Promotes Proper DNA Repair by Activating Rad16XPF and Inhibiting Dna2. PLoS Biol. 2014, 12. [CrossRef]

114. Li, F.; Dong, J.; Eichmiller, R.; Holland, C.; Minca, E.; Prakash, R.; Sung, P.; Yong Shim, E.; Surtees, J.A.; Eun Lee, S. Role of Saw1 in Rad1/Rad10 complex assembly at recombination intermediates in budding yeast. EMBO J. 2013, 32, 461-472. [CrossRef] [PubMed]

115. Balakrishnan, L.; Bambara, R.A. Flap Endonuclease 1. Annu. Rev. Biochem. 2013, 82, 119-138. [CrossRef]

116. Xu, X.; Shi, R.; Zheng, L.; Guo, Z.; Wang, L.; Zhou, M.; Zhao, Y.; Tian, B.; Truong, K.; Chen, Y.; Shen, B.; Hua, Y.; Xu, H. SUMO-1 modification of FEN1 facilitates its interaction with Rad9-Rad1-Hus1 to counteract DNA replication stress. J. Mol. Cell Biol. 2018. [CrossRef] [PubMed]

117. Kang, M.J.; Lee, C.H.; Kang, Y.H.; Cho, I.T.; Nguyen, T.A.; Seo, Y.S. Genetic and functional interactions between Mus81-Mms4 and Rad27. Nucleic Acids Res. 2010, 38, 7611-7625. [CrossRef] [PubMed]

118. Thu, H.P.T.; Nguyen, T.A.; Munashingha, P.R.; Kwon, B.; Van, Q.D.; Seo, Y.S. A physiological significance of the functional interaction between Mus81 and Rad27 in homologous recombination repair. Nucleic Acids Res. 2015, 43, 1684-1699. [CrossRef] [PubMed]

119. Shin, Y.K.; Amangyeld, T.; Nguyen, T.A.; Munashingha, P.R.; Seo, Y.S. Human MUS81 complexes stimulate flap endonuclease 1. FEBS J. 2012, 279, 2412-2430. [CrossRef] [PubMed]

120. Wang, W.; Bambara, R.A. Human bloom protein stimulates flap endonuclease 1 activity by resolving DNA secondary structure. J. Biol. Chem. 2005, 280, 5391-5399. [CrossRef] [PubMed]

121. Brosh, R.M.; Von Kobbe, C.; Sommers, J.A.; Karmakar, P.; Opresko, P.L.; Piotrowski, J.; Dianova, I.; Dianov, G.L.; Bohr, V.A. Werner syndrome protein interacts with human Ap endonuclease 1 and stimulates its cleavage activity. EMBO J. 2001, 20, 5791-5801. [CrossRef] [PubMed]

122. Zheng, L.; Zhou, M.; Chai, Q.; Parrish, J.; Xue, D.; Patrick, S.M.; Turchi, J.J.; Yannone, S.M.; Chen, D.; Shen, B. Novel function of the flap endonuclease 1 complex in processing stalled DNA replication forks. EMBO Rep. 2005, 6, 83-89. [CrossRef] [PubMed]

123. Lachaud, C.; Moreno, A.; Marchesi, F.; Toth, R.; Blow, J.J. Rouse Ubiquitinated Fancd2 recruits Fan1 to stalled replication forks to prevent genome instability. Science 2016, 351, 846-849. [CrossRef]

124. Porro, A.; Berti, M.; Pizzolato, J.; Bologna, S.; Kaden, S.; Saxer, A.; Ma, Y.; Nagasawa, K.; Sartori, A.A.; Jiricny, J. FAN1 interaction with ubiquitylated PCNA alleviates replication stress and preserves genomic integrity independently of BRCA2. Nat. Commun. 2017, 8, 1-14. [CrossRef]

125. McNeil, E.M.; Melton, D.W. DNA repair endonuclease ERCC1-XPF as a novel therapeutic target to overcome chemoresistance in cancer therapy. Nucleic Acids Res. 2012, 40, 9990-10004. [CrossRef]

126. Bastin-Shanower, S.A.; Fricke, W.M.; Mullen, J.R.; Brill, S.J. The mechanism of Mus81-Mms4 cleavage site selection distinguishes it from the homologous endonuclease Rad1-Rad10. Mol. Cell. Biol. 2003, 23, 3487-3496. [CrossRef] [PubMed] 
127. Brookman, K.W.; Lamerdin, J.E.; Thelen, M.P.; Hwang, M.; Reardon, J.T.; Sancar, A.; Zhou, Z.-Q.; Walter, C.A.; Parris, C.N.; Thompson, L.H. ERCC4 (XPF) Encodes a Human Nucleotide Excision Repair Protein with Eukaryotic Recombination Homologs. Mol. Cell. Biol. 1996, 16, 6553-6562. [CrossRef] [PubMed]

128. Tian, M.; Shinkura, R.; Shinkura, N.; Alt, F.W. Growth Retardation, Early Death, and DNA Repair Defects in Mice Deficient for the Nucleotide Excision Repair Enzyme XPF. Mol. Cell. Biol. 2004, 24, 1200-1205. [CrossRef] [PubMed]

129. Mazón, G.; Lam, A.F.; Ho, C.K.; Kupiec, M.; Symington, L.S. The Rad1-Rad10 nuclease promotes chromosome translocations between dispersed repeats. Nat. Struct. Mol. Biol. 2012, 19, 964-971. [CrossRef]

130. Munoz-Galvan, S.; Tous, C.; Blanco, M.G.; Schwartz, E.K.; Ehmsen, K.T.; West, S.C.; Heyer, W.-D.; Aguilera, A. Distinct Roles of Mus81, Yen1, Slx1-Slx4, and Rad1 Nucleases in the Repair of Replication-Born Double-Strand Breaks by Sister Chromatid Exchange. Mol. Cell. Biol. 2012, 32, 1592-1603. [CrossRef]

131. Saito, T.T.; Lui, D.Y.; Kim, H.M.; Meyer, K.; Colaiácovo, M.P. Interplay between Structure-Specific Endonucleases for Crossover Control during Caenorhabditis elegans Meiosis. PLoS Genet. 2013, 9. [CrossRef] [PubMed]

132. Kikuchi, K.; Narita, T.; Pham, V.T.; Iijima, J.; Hirota, K.; Keka, I.S.; Mohiuddin; Okawa, K.; Hori, T.; Fukagawa, T.; et al. Structure-specific endonucleases Xpf and Mus81 play overlapping but essential roles in DNA repair by homologous recombination. Cancer Res. 2013, 73, 4362-4371. [CrossRef] [PubMed]

133. Lehmann, J.; Seebode, C.; Smolorz, S.; Schubert, S.; Emmert, S. XPF knockout via CRISPR/Cas9 reveals that ERCC1 is retained in the cytoplasm without its heterodimer partner XPF. Cell. Mol. Life Sci. 2017, 74, 2081-2094. [CrossRef] [PubMed]

134. Hodskinson, M.R.G.; Silhan, J.; Crossan, G.P.; Garaycoechea, J.I.; Mukherjee, S.; Johnson, C.M.; Schärer, O.D.; Patel, K.J. Mouse SLX4 Is a Tumor Suppressor that Stimulates the Activity of the Nuclease XPF-ERCC1 in DNA Crosslink Repair. Mol. Cell 2014, 54, 472-484. [CrossRef] [PubMed]

135. Klein Douwel, D.; Boonen, R.A.C.M.; Long, D.T.; Szypowska, A.A.; Räschle, M.; Walter, J.C.; Knipscheer, P. XPF-ERCC1 Acts in Unhooking DNA Interstrand Crosslinks in Cooperation with FANCD2 and FANCP/SLX4. Mol. Cell 2014, 54, 460-471. [CrossRef] [PubMed]

136. Lachaud, C.; Castor, D.; Hain, K.; Munoz, I.; Wilson, J.; MacArtney, T.J.; Schindler, D.; Rouse, J. Distinct functional roles for the two SLX4 ubiquitin-binding UBZ domains mutated in Fanconi anemia. J. Cell Sci. 2014, 127, 2811-2817. [CrossRef]

137. Becker, J.R.; Gallo, D.; Leung, W.; Croissant, T.; Thu, Y.M.; Nguyen, H.D.; Starr, T.K.; Brown, G.W.; Bielinsky, A.-K. Flap endonuclease overexpression drives genome instability and DNA damage hypersensitivity in a PCNA-dependent manner. Nucleic Acids Res. 2018, 1-17. [CrossRef]

138. Pedersen, R.T.; Kruse, T.; Nilsson, J.; Oestergaard, V.H.; Lisby, M. TopBP1 is required at mitosis to reduce transmission of DNA damage to G1 daughter cells. J. Cell Biol. 2015, 210, 565-582. [CrossRef] [PubMed]

139. Henson, J.D.; Reddel, R.R. Assaying and investigating Alternative Lengthening of Telomeres activity in human cells and cancers. FEBS Lett. 2010, 584, 3800-3811. [CrossRef]

140. Sarkar, J.; Wan, B.; Yin, J.; Vallabhaneni, H.; Horvath, K.; Kulikowicz, T.; Bohr, V.A.; Zhang, Y.; Lei, M.; Liu, Y. SLX4 contributes to telomere preservation and regulated processing of telomeric joint molecule intermediates. Nucleic Acids Res. 2015, 43, 5912-5923. [CrossRef] [PubMed]

141. Sobinoff, A.P.; Allen, J.A.; Neumann, A.A.; Yang, S.F.; Walsh, M.E.; Henson, J.D.; Reddel, R.R.; Pickett, H.A. BLM and SLX4 play opposing roles in recombination-dependent replication at human telomeres. EMBO J. 2017, 36, e201796889. [CrossRef] [PubMed]

142. Malacaria, E.; Franchitto, A.; Pichierri, P. SLX4 prevents GEN1-dependent DSBs during DNA replication arrest under pathological conditions in human cells. Sci. Rep. 2017, 7, 44464. [CrossRef] [PubMed]

143. Guervilly, J.H.; Takedachi, A.; Naim, V.; Scaglione, S.; Chawhan, C.; Lovera, Y.; Despras, E.; Kuraoka, I.; Kannouche, P.; Rosselli, F.; Gaillard, P.H.L. The SLX4 complex is a SUMO E3 ligase that impacts on replication stress outcome and genome stability. Mol. Cell 2015, 57, 123-137. [CrossRef] [PubMed]

144. Ouyang, J.; Garner, E.; Hallet, A.; Nguyen, H.D.; Rickman, K.A.; Gill, G.; Smogorzewska, A.; Zou, L. Noncovalent Interactions with SUMO and Ubiquitin Orchestrate Distinct Functions of the SLX4 Complex in Genome Maintenance. Mol. Cell 2015, 57, 108-122. [CrossRef] [PubMed]

145. Guo, Z.; Qian, L.; Liu, R.; Dai, H.; Zhou, M.; Zheng, L.; Shen, B. Nucleolar localization and dynamic roles of flap endonuclease 1 in ribosomal DNA replication and damage repair. Mol. Cell. Biol. 2008, 28, 4310-4319. [CrossRef] [PubMed] 
146. Saharia, A.; Teasley, D.C.; Duxin, J.P.; Dao, B.; Chiappinelli, K.B.; Stewart, S.A. FEN1 ensures telomere stability by facilitating replication fork re-initiation. J. Biol. Chem. 2010, 285, 27057-27066. [CrossRef]

147. Teasley, D.C.; Parajuli, S.; Nguyen, M.; Moore, H.R.; Alspach, E.; Lock, Y.J.; Honaker, Y.; Saharia, A.; Piwnica-Worms, H.; Stewart, S.A. Flap endonuclease 1 limits telomere fragility on the leading strand. J. Biol. Chem. 2015, 290, 15133-15145. [CrossRef] [PubMed]

148. Jin, H.; Cho, Y. Structural and functional relationships of FAN1. DNA Repair (Amst). 2017, 56, 135-143. [CrossRef]

149. Chaudhury, I.; Stroik, D.R.; Sobeck, A. FANCD2-Controlled Chromatin Access of the Fanconi-Associated Nuclease FAN1 Is Crucial for the Recovery of Stalled Replication Forks. Mol. Cell. Biol. 2014, 34, 3939-3954. [CrossRef]

150. MacKay, C.; Déclais, A.C.; Lundin, C.; Agostinho, A.; Deans, A.J.; MacArtney, T.J.; Hofmann, K.; Gartner, A.; West, S.C.; Helleday, T.; Lilley, D.M.J.; Rouse, J. Identification of KIAA1018/FAN1, a DNA Repair Nuclease Recruited to DNA Damage by Monoubiquitinated FANCD2. Cell 2010, 142, 65-76. [CrossRef]

151. Rao, T.; Longerich, S.; Zhao, W.; Aihara, H.; Sung, P.; Xiong, Y. Importance of homo-dimerization of Fanconi-associated nuclease 1 in DNA flap cleavage. DNA Repair (Amst). 2018, 64, 53-58. [CrossRef] [PubMed]

152. Zhao, X.N.; Usdin, K. FAN1 protects against repeat expansions in a Fragile X mouse model. DNA Repair (Amst). 2018, 69, 1-5. [CrossRef]

153. Blanco, M.G.; Matos, J. Hold your horSSEs: Controlling structure-selective endonucleases MUS81 and Yen1/GEN1. Front. Genet. 2015, 6, 1-11. [CrossRef] [PubMed]

154. Chang, H.H.Y.; Lieber, M.R. Structure-Specific nuclease activities of Artemis and the Artemis: DNA-PKcs complex. Nucleic Acids Res. 2016, 44, 4991-4997. [CrossRef] [PubMed]

155. Mayle, R.; Campbell, I.M.; Beck, C.R.; Yu, Y.; Wilson, M.; Shaw, C.A.; Bjergbaek, L.; Lupski, J.R.; Ira, G. Mus81 and converging forks limit the mutagenicity of replication fork breakage. Science 2015, 349, 742-747. [CrossRef] [PubMed]

156. Watanabe, T.; Tanaka, H.; Horiuchi, T. Complex repeat structure promotes hyper-amplification and amplicon evolution through rolling-circle replication. Nucleic Acids Res. 2018, 46, 5097-5108. [CrossRef] [PubMed]

157. Elango, R.; Sheng, Z.; Jackson, J.; Decata, J.; Ibrahim, Y.; Pham, N.T.; Liang, D.H.; Sakofsky, C.J.; Vindigni, A.; Lobachev, K.S.; Ira, G.; Malkova, A. Break-induced replication promotes formation of lethal joint molecules dissolved by Srs2. Nat. Commun. 2017, 8. [CrossRef] [PubMed]

158. Wu, F.; Li, T.Y.; Su, S.C.; Yu, J.S.; Zhang, H.L.; Tan, G.Q.; Liu, J.W.; Wang, B.L. STC2 as a novel mediator for Mus81-dependent proliferation and survival in hepatocellular carcinoma. Cancer Lett. 2017, 388, 177-186. [CrossRef]

159. Wu, F.; Su, S.C.; Tan, G.Q.; Yan, L.; Li, T.Y.; Zhang, H.L.; Yu, J.S.; Wang, B.L. Mus81 knockdown sensitizes colon cancer cells to chemotherapeutic drugs by activating CHK1 pathway. Clin. Res. Hepatol. Gastroenterol. 2017, 41, 592-601. [CrossRef] [PubMed]

160. Ho, S.S.W.; Zhang, W.Y.L.; Tan, N.Y.J.; Khatoo, M.; Suter, M.A.; Tripathi, S.; Cheung, F.S.G.; Lim, W.K.; Tan, P.H.; Ngeow, J.; Gasser, S. The DNA Structure-Specific Endonuclease MUS81 Mediates DNA Sensor STING-Dependent Host Rejection of Prostate Cancer Cells. Immunity 2016, 44, 1177-1189. [CrossRef] [PubMed]

(C) 2018 by the authors. Licensee MDPI, Basel, Switzerland. This article is an open access article distributed under the terms and conditions of the Creative Commons Attribution (CC BY) license (http:// creativecommons.org/licenses/by/4.0/). 